\title{
Numerical modeling of the Patos Lagoon coastal plume, Brazil
}

\author{
W.C. Marques *, E.H. Fernandes, I.O. Monteiro, O.O. Möller \\ Fundação Universidade Federal do Rio Grande (FURG), Departamento de Física · Laboratório de Oceanografia Física, CP 474, 96200-900 Rio Grande RS, Brazil
}

\section{A R T I C L E I N F O}

\section{Article history:}

Accepted 24 September 2008

Available online 21 October 2008

Keywords:

Coastal plume

Southern Brazilian Shelf

Freshwater

Numerical modeling

EOF analysis

\begin{abstract}
A B S T R A C T
The Southern Brazilian Shelf (SBS) is a freshwater-influenced region, but studies on the dynamics of coastal plumes are sparse and lack in space-time resolution. Studies on the dynamics of the Patos Lagoon plume are even more limited. The aim of this paper is to investigate the influence of the principal physical forcing for the formation and behavior of the Patos Lagoon coastal plume. The study is carried out through 3D numerical modeling experiments and empirical orthogonal function (EOF) analysis. Results showed that the amount of freshwater is the principal physical forcing controlling the plume formation. The Coriolis effect enhances the northward transport over the shelf, while the tidal effects contribute to intensify horizontal and vertical mixing, which are responsible for spreading the freshwater over the shelf. The wind effect, on the other hand, is the main mechanism controlling the behavior of the Patos Lagoon coastal plume over the inner SBS in synoptic time scales. Southeasterly and southwesterly winds contribute to the northeastward displacement of the plume, breaking the vertical stratification of the inner continental shelf. Northeasterly and northwesterly winds favor ebb conditions in the Patos Lagoon, contributing to the southwestward displacement of the plume enhancing the vertical stratification along and across-shore. The EOF analysis reveals two modes controlling the variability of the plume on the surface. The first mode (explaining $70 \%$ of the variability) is associated to the southwestward transportation of the plume due to the dominance of north quadrant winds, while the second mode (explaining $19 \%$ of the variability) is associated to the intermittent migration of the plume northeastward due to the passage of frontal systems over the area. Large scale plumes can be expected during winter and spring months, and are enhanced during El Niño events.
\end{abstract}

(c) 2008 Elsevier Ltd. All rights reserved.

\section{Introduction}

Continental shelves receive water and suspended matter transported via river discharge towards the coast. The dynamic structure formed by this process is a buoyant low-density water mass with high suspended matter concentration, namely coastal plume. The region where oceanic and continental water masses meet is marked by the presence of foam and debris lines, together with significant color and property gradients (Garvine and Monk, 1974). The input of materials and interaction between continental waters and coastal processes can contribute to the maintenance of a favorable environment for reproduction, development of species, sustainable deposition and transport patterns.

Several studies present the influence of continental discharge on the intensification of biological activities and maintenance of

\footnotetext{
* Corresponding author at: Universidade Federal do Rio Grande-FURG, Instituto de Oceanografia-Oceanografia Física, Laboratório de Oceanografia Costeira e Estuarina, Av. Itália Km 08, 96201-900 Rio Grande (RS), Brasil.

Tel.: +555332336643.

E-mail addresses: wilian_marques@yahoo.com.br (W.C. Marques), dfsehf@furg.br (E.H. Fernandes), igoromonteiro@yahoo.com.br (I.O. Monteiro), dfsomj@furg.br (O.O. Möller).
}

fishing stocks in estuarine and coastal zones (Mann and Lazier, 1991). Estuarine ecosystems are sustained by the continuous supply of continental sediments to the marine environment (Hutchinson et al., 1995), which are transported along the coast by a variety of process (Wright and Nittrouer, 1995; Wright and Friedrichs, 2006; Blaas et al., 2007; Wang et al., 2007). Geyer et al. (2004) and Wright and Friedrichs (2006) concluded that the density anomaly between the fresh and coastal waters induces important consequences on the delivery, transport and ultimate fate of continental sediment.

The fate and behavior of coastal plumes is controlled by linear and nonlinear processes, and their study can be accomplished through field data analysis, remote sensing and analytical and numerical models. Most of the investigations about the dynamics of coastal plumes were developed in the coastal regions of North America. Garvine and Monk (1974) conducted a pioneer study on the dynamics of the front formed by the Connecticut River plume, Long Island, based on direct measurements. The interaction between coastal plumes and wind driven coastal currents was investigated by Blanton (1981) on the South Atlantic Bight, and by Gelfenbaum and Stumpf (1993) in Mobile Bay. Dinnel et al. (1990) used Landsat images to estimate the exchange of suspended sediment between the estuary and the shelf in Mobile Bay. Hickey 
et al. (1998) used direct measurements to show that the Columbia River plume is driven by the intensity and direction of the dominant winds.

However, the study of plumes sometimes requests the consideration of complex effects, which can be better addressed by numerical modeling techniques. Garvine (1981, 1982), O'Donnel and Garvine (1983), Garvine (1987), and O'Donnel (1990) conducted a series of numerical experiments for the Connecticut River applying a numerical model which considers coastal plumes as discontinuities. These studies considered different conditions of river discharge under the influence of the Coriolis effect, nonlinear advection terms, time dependency, mixing process and friction, indicating the most important characteristics about the fate and behavior of the coastal plumes. Furthermore, the development of nonlinear models of ocean circulation became an important tool to study the evolution of coastal plumes. These models became popular and were used by several authors around the world (Royer and Emery, 1985; Chao and Boicourt, 1986; Chao, 1988a, b; Chapman and Lentz, 1993; Kourafalou et al., 1996a, b; Garvine, 1999; Fong and Geyer, 2001, 2002, among others). Although these models were forced by the fluvial discharge in coastal regions, each of them considered different forcing and dissipative effects, and their results indicated as a common feature the formation of a bulge near the estuarine mouth that is later deflected anti-cyclonically to form a coastal current on the Kelvin wave direction.

The wind influence on the coastal plume dynamics was considered in numerical modeling studies carried out by Royer and Emery (1985), Chao (1988b), Kourafalou et al. (1996a, b), and Xia et al. (2007). These studies elucidated the contribution of upwelling favorable winds in the offshore exportation of freshwater on the surface Ekman layer, as well as the contribution of upwelling non-favorable winds in trapping freshwater along the coast, increasing the mixing process and inducing the coastal current formation. A modulation effect was attributed to the tidal action, which contributes to mixing process, reduces the stratification created by the wind and spreads the freshwater over the shelf (Chao, 1990; Garvine, 1999; Pritchard, 2000; Guo and ValleLevinson, 2007).

Studies on the dynamics of plumes in the Southern Brazilian Shelf (SBS) (Fig. 1A) are sparse. The SBS is located between $28^{\circ} \mathrm{S}$ and $35^{\circ} \mathrm{S}$, and receives freshwater contributions from the La Plata River and the Patos Lagoon, which are advected by local coastal currents. At the southern boundary of the SBS, the La Plata River, the second main hydrographic basin of South America, discharges an annual mean of $22,000 \mathrm{~m}^{3} \mathrm{~s}^{-1}$ of freshwater in the coastal zone (Framiñan and Brown, 1996; Guerrero et al., 1997). Towards the north, the Patos Lagoon discharges on average ten times less water over the shelf, and presents seasonal and inter-annual discharge variability.

Numerical modeling studies on the SBS lack in space-time resolution (Ghisolfi, 2001; Piola et al., 2005; Soares et al., 2007a, b). Therefore their results were limited to considering the large scale coastal currents. Ghisolfi (2001) verified through simplified three dimension simulations that the alternation of the wind pattern can propagate the La Plata river front further seaward, but the background flow constrains the frontal structure close to the coast. Soares et al. (2007a, b) carried out more realistic hydrodynamic simulations for the SBS. These authors investigated the buoyancy-driven currents on the area, highlighting the contributions of the wind and tidal currents.

Previous studies on the dynamics of the Patos Lagoon coastal plume considering the related small scale process are even more limited, and do not involve numerical modeling techniques. Hartmann and Silva (1989), observed the wind contribution for the river plume formation under low to moderate discharge conditions. More recently, Zavialov et al. (2003) monitored the behavior of this plume under intense river runoff conditions using salinity and temperature observations. Burrage et al. (2008) investigated the interaction of the Patos Lagoon plume and the La Plata river buoyancy-driven currents using airborne data. However, no further studies considering the importance of the principal forcing effects controlling the fate and behavior of the Patos Lagoon coastal plume in synoptic time scales were carried out. Therefore, the objective of this study is to investigate the influence of the principal physical forcing, namely the river discharge, the Coriolis effect, the tides and the winds to the formation and behavior of the Patos Lagoon coastal plume, providing a specific insight on the short timescale variability of the inner SBS hydrodynamics.

\section{Description of the study area}

The SBS (Fig. 1A) is relatively smooth. The continental shelf is narrow in the northern part $(110 \mathrm{~km})$ and widens up to $170 \mathrm{~km}$ in the south. The shelf break is located around the $180 \mathrm{~m}$ isobath. The inner shelf is dominated by coastal currents originated at the Patagônia coast (Piola and Rivas, 1997) and by the La Plata River discharge (Framiñan and Brown, 1996; Guerrero et al., 1997). The outer shelf is influenced by the Brazil and Malvinas western boundary currents (Castro and Miranda, 1998).

The SBS is considered one the most important fishing zones of the Brazilian coast (Castello et al., 1990). The freshwater discharge pattern and the upwelling process on the shelf break enhance the phytoplankton biomass on the SBS (Ciotti et al., 1995), where annual mean rates of primary production around $160 \mathrm{~g} \mathrm{Cm}^{-2}$ year ${ }^{-1}$ were observed by Odebrecht and Garcia (1996).

The Patos lagoon is located in the southernmost part of Brazil, between $30^{\circ}-32^{\circ} \mathrm{S}$ and $50^{\circ}-52^{\circ} \mathrm{W}$, being connected to the Atlantic Ocean by a single channel less than $1 \mathrm{~km}$ wide (Fig. 1C). The principal rivers contributing at the north of the lagoon have a mean annual discharge of $2400 \mathrm{~m}^{3} \mathrm{~s}^{-1}$. This lagoon responds to a temperate climate, also presenting large inter-annual variability associated with El Niño Southern Oscillation events (Marques, 2005). The influence of the South Atlantic anticyclone and of anticyclones of polar origin contributes to the high spatial variability of the wind circulation at synoptic time scales. The tides are mixed, with diurnal dominance, and their effects are restricted to the coastal zone and the estuarine region of the Patos Lagoon (Möller et al., 2001).

\section{Methodology}

\subsection{The numerical model}

The TELEMAC SYSTEM, developed by CEDF-Laboratoire National d'Hydraulique et Environnement of the Company Eletricite de France (EDF) is used for the numerical simulations. The TELEMAC SYSTEM presents a modular structure which works in two and three dimensions, offering modules for hydrodynamic, sediment transport, waves and water quality studies in rivers, estuaries, coastal and oceanic zones. The TELEMAC3D model was used to investigate the dynamics of the Patos Lagoon plume. This model solves the Navier Stokes equations considering the local variations in the free surface of the fluid, ignoring the density variations in the mass conservation equation, and considering the hydrostatic pressure and Boussinesq approximations to solve the motion equations. The model is based on the characteristics methods and finite element technique to solve the hydrodynamic equations (Hervouet, 2007). The continuity and motion equations are 

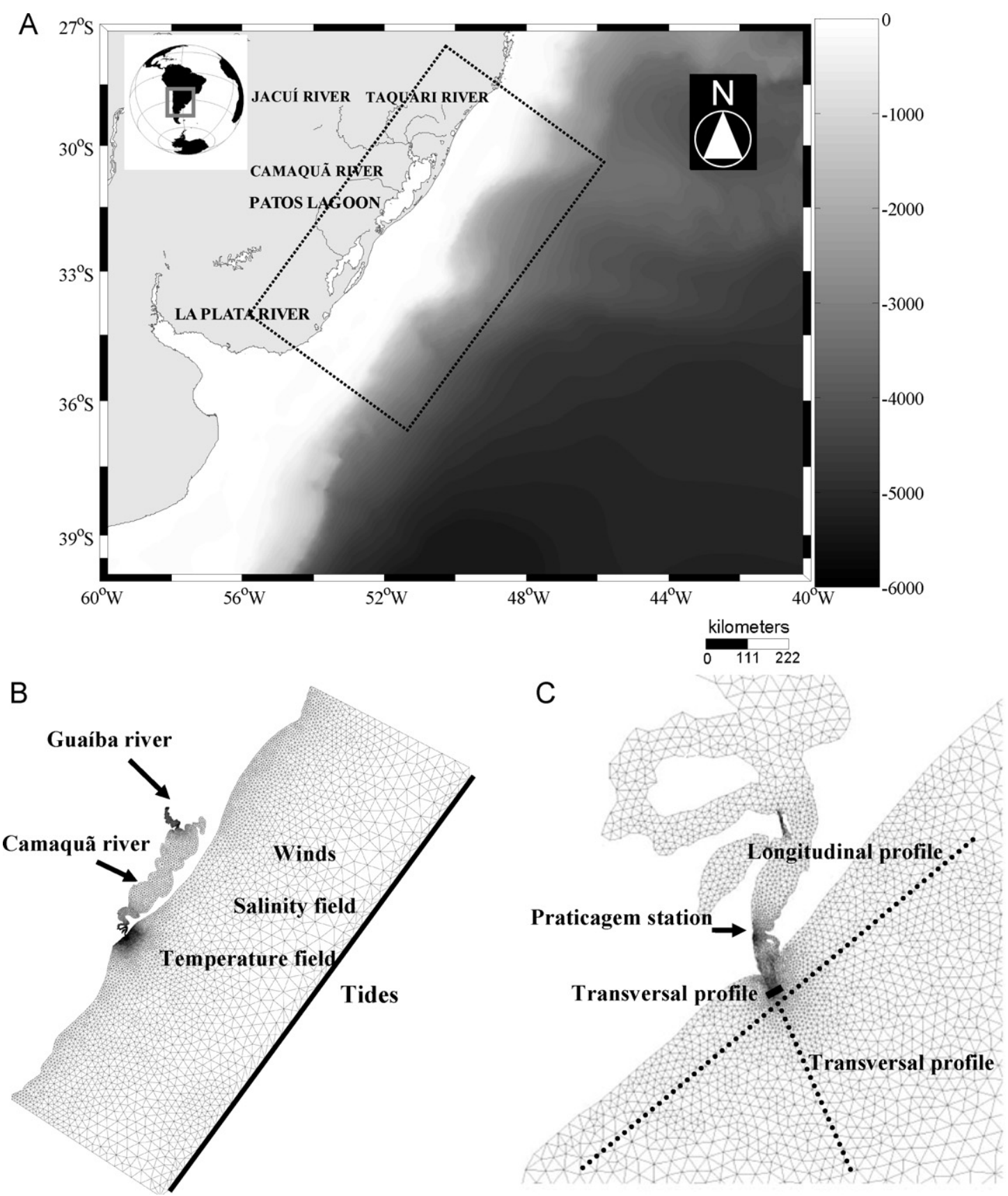

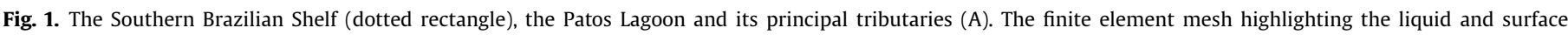

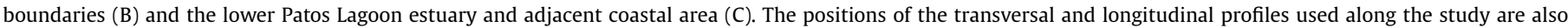
presented.

written as:

$\frac{\partial u}{\partial x}+\frac{\partial v}{\partial y}+\frac{\partial w}{\partial z}=0$

$\frac{\partial u}{\partial t}+\vec{u} \vec{\nabla}(u)=-\frac{1}{\rho_{0}} \frac{\partial p}{\partial x}+\operatorname{div}\left(v_{H} u\right)+F_{X}$

$\frac{\partial v}{\partial t}+\vec{u} \vec{\nabla}(v)=-\frac{1}{\rho_{0}} \frac{\partial p}{\partial y}+\operatorname{div}\left(v_{H} v\right)+F_{y}$

$p=\rho_{0} g(S-z)+\rho_{0} g \int_{z}^{S} \frac{\Delta \rho}{\rho_{0}} \mathrm{~d} z$

where $x, y$ represent the horizontal spatial coordinates $(\mathrm{m}), z$ represents the vertical spatial coordinate $(\mathrm{m}), F_{x}, F_{y}$ are the source or sink terms in the dynamic equations $\left(\mathrm{m} \mathrm{s}^{-2}\right), \rho_{0}$, is the reference density $\left(\mathrm{kg} \mathrm{m}^{-3}\right), p$ represents the pressure $\left(\mathrm{N} \mathrm{m}^{-2}\right), g$ is the gravity acceleration $\left(\mathrm{m} \mathrm{s}^{-2}\right), t$ represents the time $(\mathrm{s}), u, v$ and $w$ are the velocity components $\left(\mathrm{m} \mathrm{s}^{-1}\right), S$ is the free surface elevation (m) and $v_{H}$ represents the turbulent viscosity coefficient $\left(\mathrm{m}^{2} \mathrm{~s}^{-1}\right) . F_{x}$ and $F_{y}$ are the source terms representing the wind, Coriolis, bottom friction. The TELEMAC model calculates the salinity concentration based on the mass conservation law:

$\frac{\partial T}{\partial t}+\vec{u} \vec{\nabla}(T)=\operatorname{div}\left(v_{T} T\right)+Q$

where $T$ represents the concentration of the non-buoyant tracer $\left(\mathrm{g} \mathrm{l}^{-1}\right.$ or $\left.{ }^{\circ} \mathrm{C}\right), Q$ the source or sink term of tracer $\left(\mathrm{gl} \mathrm{s}^{-1}\right)$, and $v_{T}$ the diffusion coefficient of tracer $\left(\mathrm{m}^{2} \mathrm{~s}^{-1}\right)$. 
The time step of $90 \mathrm{~s}$ and the Coriolis coefficient of $-7.70 \times 10^{-5} \mathrm{~N} \mathrm{~m}^{-1} \mathrm{~s}^{-1}$ (latitude $32^{\circ} \mathrm{S}$ ) were used in all the simulations. The Manning law of bottom friction has been successfully applied in previous studies of the Patos Lagoon hydrodynamics by Fernandes et al. (2001, 2005). The same approach was used in this study considering a constant roughness Manning coefficient of 0.04 . The horizontal turbulence process was performed using the Smagorinsky model. This closure turbulent model is generally used for maritime domains with large scale eddy phenomena, calculating the mixing coefficient considering the size of the mesh elements and the velocity field (Smagorinski, 1963). The mixing length model for buoyant jets was implemented to access the vertical turbulence process, giving a better representation of the stratification and the vertical mixing process. This model calculates de turbulent viscosity using the Prandtl's hypotheses of the mixing length scale. The mixing scale is calculated algebraically but the velocity of the movement is obtained from the turbulent kinetic energy calculated through the balance equation. The model takes into account density effects via a damping factor which depends on the Richardson number to calculate the vertical diffusion coefficients. According to Hervouet (2007), the use of traditional mixing length models lead to abnormal results in the case of outflows but the dissipation is overestimated in the vicinity of an outflow. In this sense, Rodi
(1984) proposed the mixing length model for buoyant jets considering a mixing length scale of about $8 \%$ of the half-height of the jet, defined as the distance between the elevation of the jet axis and the one where the velocity does not exceed $1 \%$ of its value on the axis. The half-height of the jet is a necessary data in this case and during all the simulations the value of $10 \mathrm{~m}$ was considered for the mixing length scale.

\subsection{Model domain}

The domain of the model is defined between $28^{\circ} \mathrm{S}$ and $35^{\circ} \mathrm{S}$ (Fig. 1A), and the oceanic boundary is located around the $3600 \mathrm{~m}$ isobath. The resulting finite element mesh (Fig. 1B) contains 8974 nodes and 15 sigma levels to perform a structured prismatic mesh. The sigma levels are distributed to improve the representation of the surface and bottom Ekman layers, with 5 levels along the first $10 \%$ and 5 levels in the last $10 \%$ of the water column.

\subsubsection{Initial and boundary conditions}

Initial conditions of salinity, temperature, water level and velocity fields are prescribed as initial condition for the TELEMAC3D model. Salinity and temperature fields are obtained from the OCCAM Project (Ocean Circulation and Climate Advanced

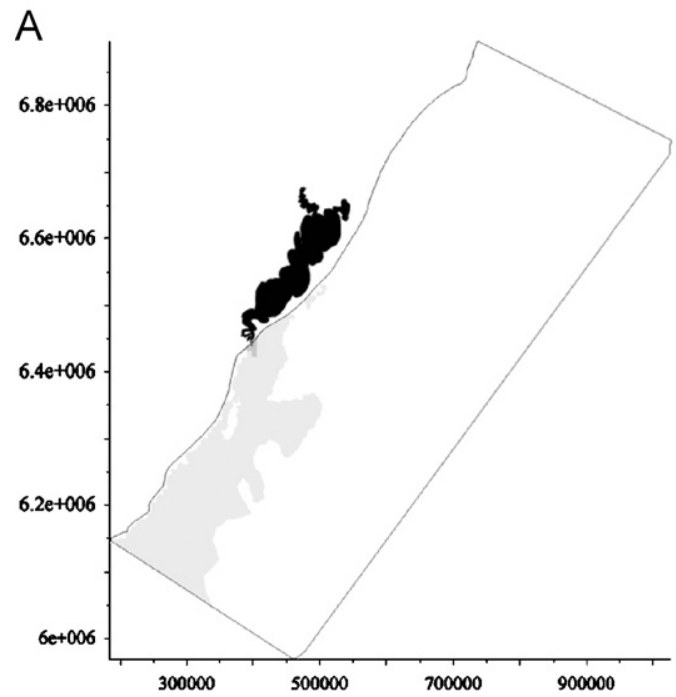

B
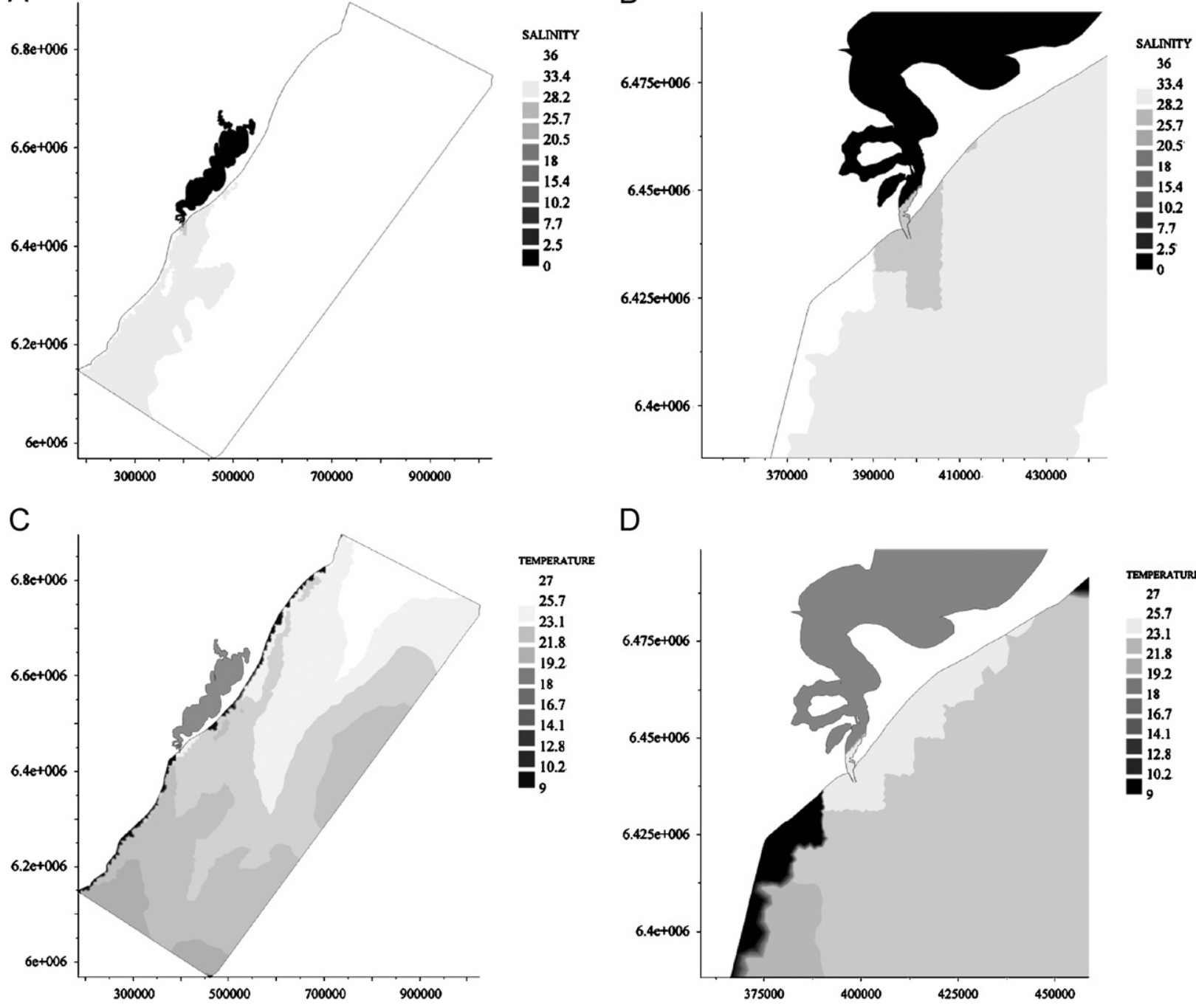

D
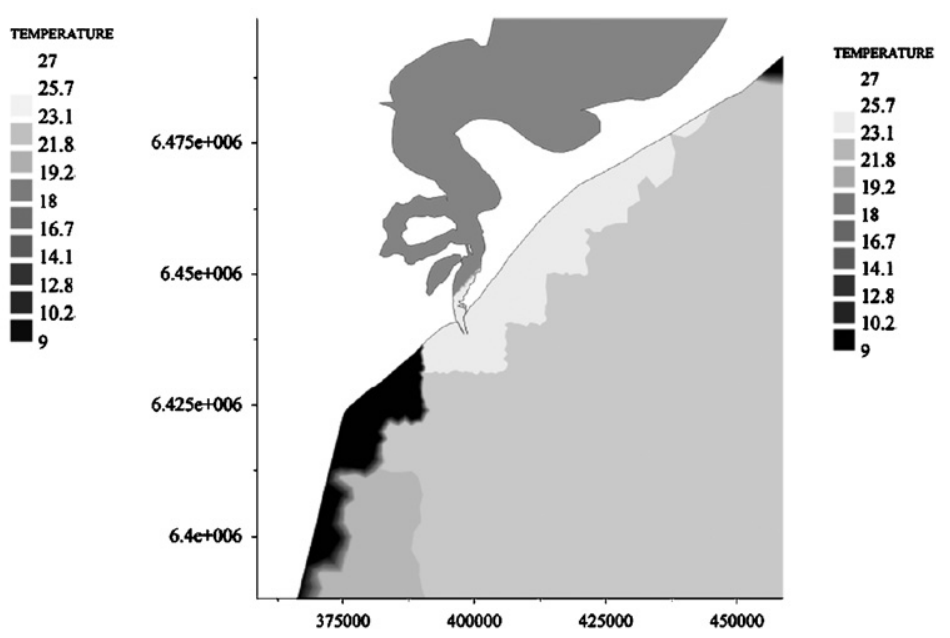

Fig. 2. Surface (A) and bottom (B) salinity fields. Surface (C) and bottom (D) temperature fields. Both data are from January 1998. 
Modeling Project-http://www.soc.soton.ac.uk/), and prescribed tri-dimensionally over the entire domain. Water levels of $0.4 \mathrm{~m}$, about the mean value of the tide in the study region, and null velocity fields are prescribed in the entire domain. The salinity and temperature along the Patos Lagoon are initialized with spatially constant values of 0 and $20^{\circ} \mathrm{C}$, respectively (Fig. $2 \mathrm{~A}$ and C). In the coastal area, the salinity and temperature fields (from OCCAM project) represent the influence of the La Plata river discharge over the SBS (Fig. 2A) and the Brazil Current along the continental shelf at the northern oceanic boundary (Fig. 2C). The zoom near the Patos Lagoon mouth suggests the local influence of the Patos Lagoon coastal plume on the Southern Brazilian inner shelf (Fig. 2B). The salinity and temperature along the oceanic boundaries (Fig. 1B) were maintained constant with the same values of the initial conditions during all the simulations.

Time series of river discharge from the principal rivers at the north of the lagoon are used to force the continental liquid boundary (Fig. 1B). According to Marques (2005), the Taquari and Jacuí rivers (tributaries of the Guaíba river) and the Camaquã river (Fig. 1A) are the principal tributaries of the Patos Lagoon. The river discharge data are provided by the Brazilian National Water Agency (www.ana.gov.br,ANA). The time series of river discharge used for the model verification ranges between April 29 and May 31, 2004 (Fig. 3). The time series of river discharge used for the case study ranges between January 1 and June 29, 1998 (Fig. 3). The higher discharge observed during the year 1998 indicates the El Niño influence on the area.

The tides are prescribed at each nodal point of the oceanic boundary (Fig. 1B) using the amplitude and phase of each of the five principal tidal components for the area (Fernandes et al., 2004), namely K1, M2, N2, O1 and S2, obtained from the Grenoble Model (FES95.2, Finite Element Solution-v.95.2). These data have initial resolution of approximately $55 \mathrm{~km}$ and have been interpolated for a $1 \mathrm{~km}$ resolution. The tidal oscillation is performed as
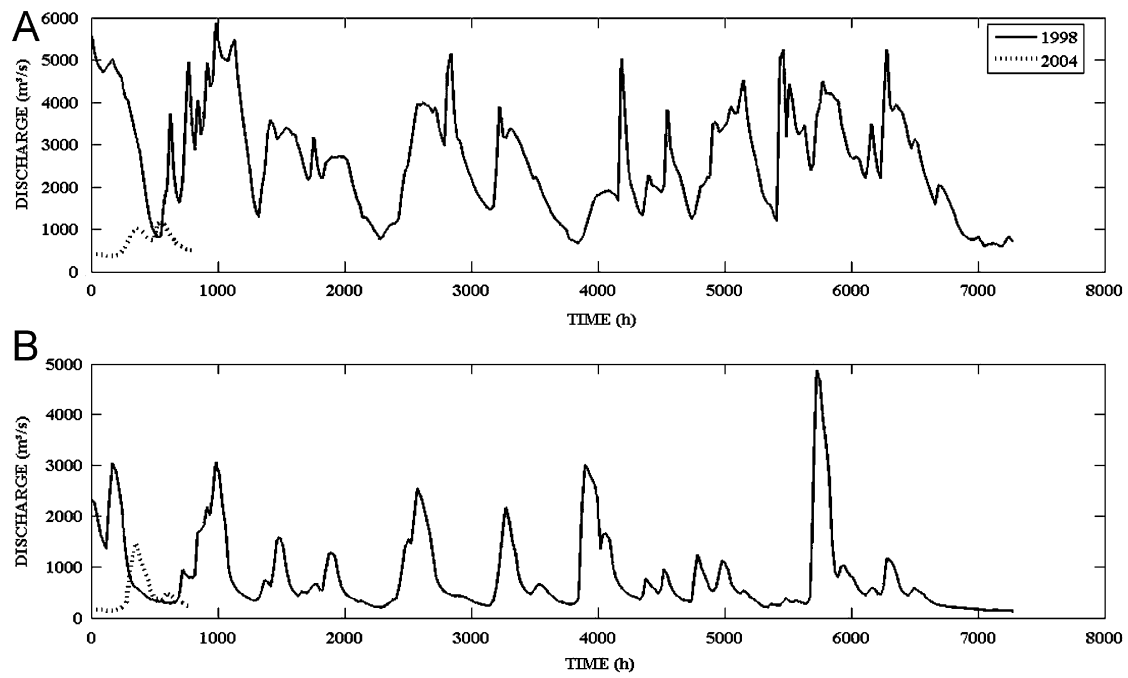

Fig. 3. Time series of river discharge for the Guaíba (Jacuí+Taquari) (A) and Camaquã (B) rivers from April 29 to May 31, 2004 , and from January 01 to June $29,1998$.
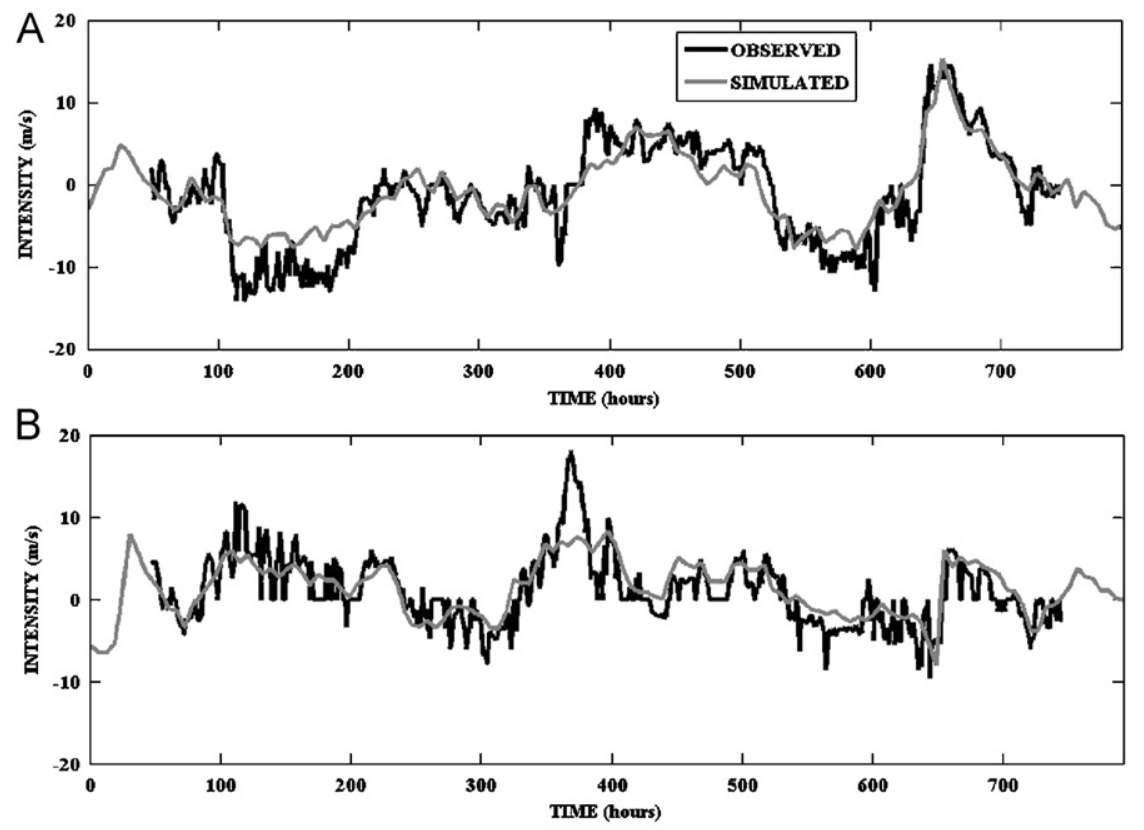

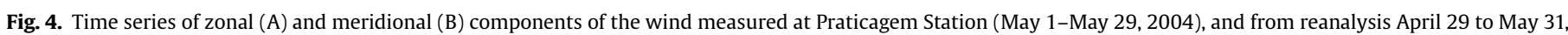
2004). Grey/black lines represent the reanalysis/Praticagem data, respectively. 
a sum of orthogonal basis of cosines functions, being calculated for each of the different nodes of the oceanic boundary at each time step of the simulation.

The surface boundary of the model is forced with space and time variable winds from reanalysis (National Oceanic \& Atmospheric Administration-NOAA, www.cdc.noaa.gov/cdc/reanalysis), which are prescribed at each nodal point of the mesh using a constant coefficient of wind influence of $1 \times 10^{-5}$. These data are obtained with spatial and temporal resolution of $2.5^{\circ}$ and $6 \mathrm{~h}$, respectively. The meridional and zonal wind components are collected between $25^{\circ} \mathrm{S} 42^{\circ} \mathrm{W}$ and $38^{\circ} \mathrm{S} 55^{\circ} \mathrm{W}$, being later interpolated using a cubic interpolation method for a $1 \mathrm{~km}$ resolution mesh. A similar methodology was adopted by Simionato et al. (2006) when using the reanalysis data to model the barotropic circulation of the La Plata River mouth.

\subsubsection{Wind data verification-from April to May, 2004}

In order to verify the suitability of the wind data for this particular modeling study, the reanalysis wind data $(6 \mathrm{~h}$ resolution) was compared with wind data measured at Praticagem Station (hourly resolution) (Fig. 4). The comparison indicates that the trends observed in the data measured at Praticagem Station are well represented by the reanalysis data. The short period oscillations, however, are not represented by the reanalysis data due to the low time resolution (6h). Simionato et al. (2006) carried out a similar analysis using reanalysis data $(24 \mathrm{~h}$ resolution) for the La Plata river region, and also observed that the highintensity events were underestimated in up to 50\% when compared with field data.

\subsection{Model verification in the estuary-April to May, 2004}

In order to verify the reproducibility of the model, results from a hydrodynamic simulation are compared with observed time series measured in the estuarine area between April and May, 2004. The observed water levels and current velocity time series are collected at Praticagem Station (Fig. 1C) using an acoustic doppler current profiler (ADCP).

The model starts from rest with real conditions of salinity and temperature. Besides the discharge in the northern boundary (Fig. 3), the model is forced with tides in the oceanic boundary, and winds on the surface boundary of the domain. The first 28 days of simulation are used to stabilize the hydrodynamics of the model, and the last 33 days of simulation (from April 29 to May 31) are used to verify the quality of the wind data.

Calculated water levels and velocity (measured 1 and $10 \mathrm{~m}$ depth) time series were obtained from the model results for the same period and location. In order to improve the comparison between the observed and simulated water level time series, a Lanczos-squared filter is used to separate the high-frequency oscillation (periods lower than $24 \mathrm{~h}$ ) of the series. The comparison between the observed and the simulated water levels for the highand low-frequency oscillations are presented in Fig. 5.

Results from this verification exercise indicate that the lowfrequency water levels (Fig. 5A) calculated by the model can reproduce the general trends measured in the field, although overestimating the magnitude and presenting phase lags in relation to the observed data during specific events. Möller et al. (2001) and Fernandes et al. (2005) comment that the main factors controlling the dynamics of the estuarine region of the Patos Lagoon are the freshwater discharge and the winds acting on subtidal time scales (periods higher than $24 \mathrm{~h}$ ). Thus, the observed differences between measurements and modeling results are likely to be related to the use of reanalysis low-resolution wind data and to the lack of data from the freshwater discharge of the Taquari river.

The calculated high-frequency water levels (Fig. 5B) present good correlation with observations. Phase lags are not observed and small differences in amplitude occur during periods of maximum and minimum intensity. These results indicate that the Global model FES95.2 supplies reliable information about the amplitude and phase of the tides. Furthermore, results suggest that the TELEMAC3D model reproduces the propagation of the tidal waves over the region, apart from the difficulties related to the reproduction of nonlinearities in the estuarine high-frequency oscillation.

The comparison between the calculated and observed current velocity (Fig. 6A and B) at 1 and $10 \mathrm{~m}$ depth indicates that the model can reproduce the real variability and trends of the velocity field on the estuarine region, with small differences in the intensity and phase of the series. Thus, a general overview of this verification exercise indicate that, apart from the limitations in the observed data used to initialize and force the model, the
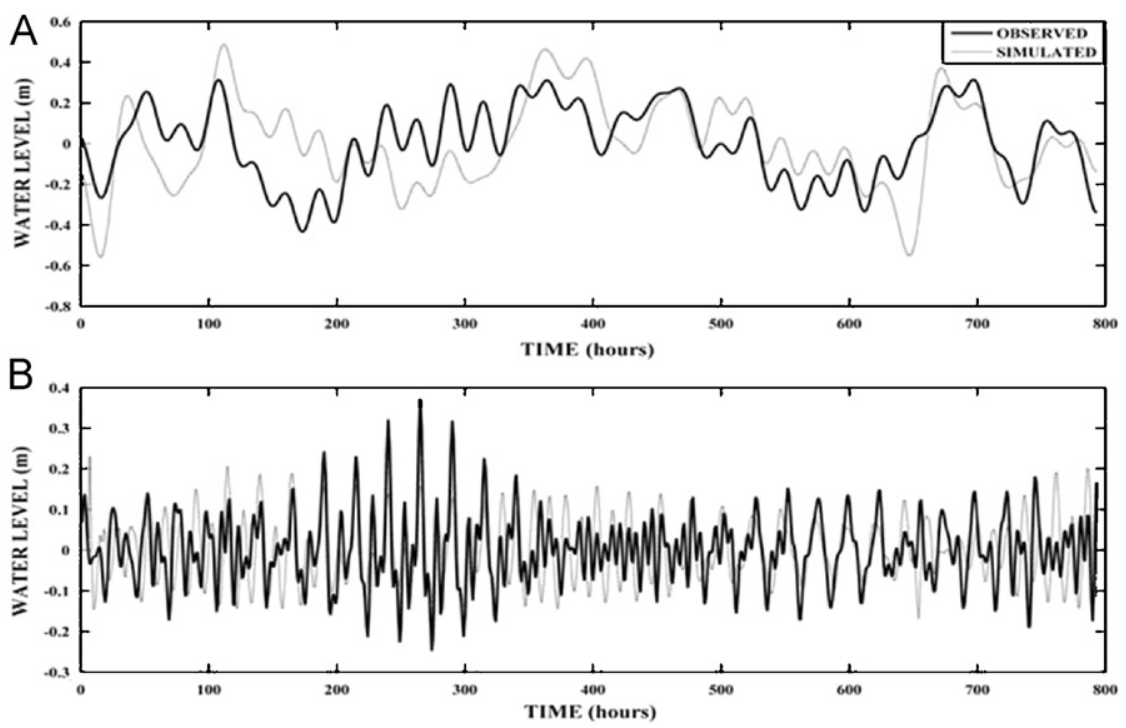

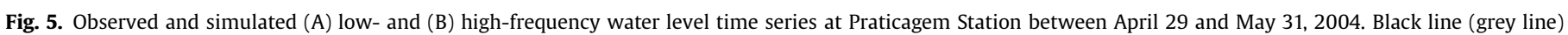
represents the observed (calculated) time series. 

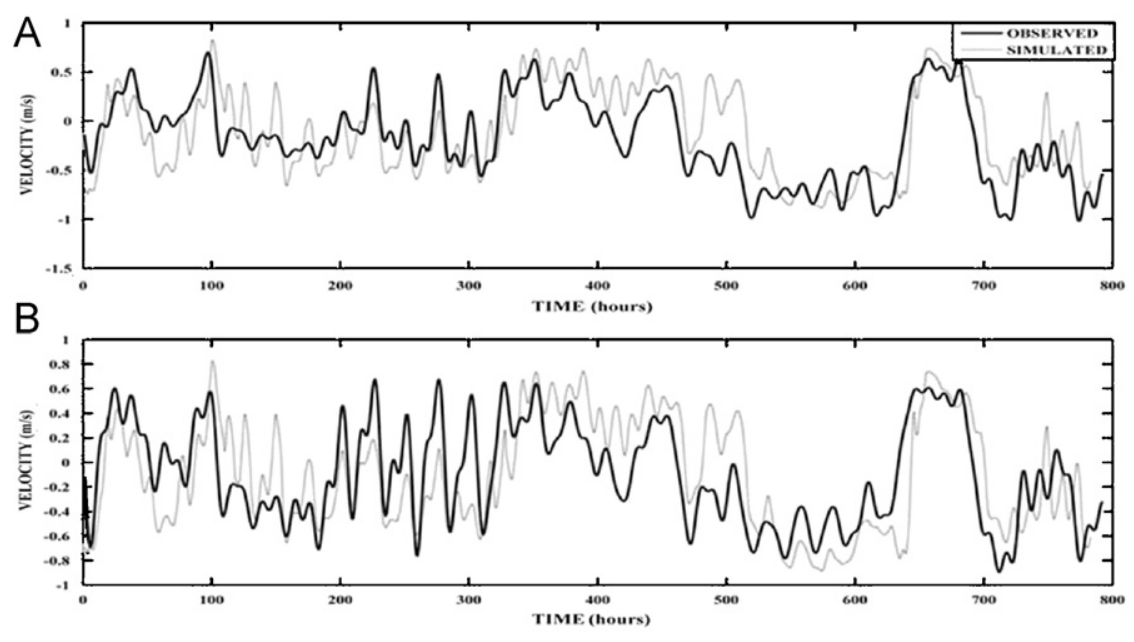

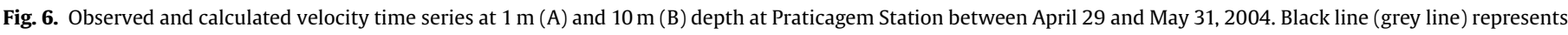
the observed (calculated) time series.

Table 1

RMAE between the measured and calculated water levels, salinity and velocity at the estuarine area.

\begin{tabular}{ll}
\hline Variable & RMAE \\
\hline Low-frequency water level & 0.76 \\
High-frequency water level & 0.76 \\
Surface velocity & 0.65 \\
Bottom velocity & 0.71 \\
\hline
\end{tabular}

calculated water levels and velocity time series satisfactory represent the trends of the signals measured inside the estuary.

In order to quantify the reproducibility of the model, the method proposed by Walstra et al. (2001) was used. This method calculates the root mean square absolute error (RMAE) between the measured and calculated time series. The calculated RMAE for this period of simulation is presented in Table 1. Results indicate that near the mouth of the estuary the model reproduction is reasonable for the water level and velocities.

\subsection{The empirical orthogonal function (EOF) analysis}

Results from the numerical experiments indicate the most important forcing controlling the formation and the behavior of the Patos Lagoon coastal plume in synoptic time scales. The analysis of the spatial and temporal variability in distinct regions of the domain, however, is not straightforward. This regional variability can be accessed using EOF analyses, which provide a compact description of the spatial and temporal variability of data series in terms of statistic modes, where most of the variance of the spatially distributed series can be observed in the first few orthogonal functions (Emery and Thomson, 1998).

The knowledge of the regions where the Patos Lagoon coastal plume is located during most part of the time is essential to identify possible regions where the fine sediments transported via river discharge can be initially deposited after reach the coastal region. According to Wright and Nittrouer (1995) the fate of sediment seaward of river and estuarine mouths can involve at least four stages: supply via plumes, initial deposition, resuspension and transport by marine processes and long-term net accumulation. The rate at which sediment is initially deposited seaward of a river mouth in the region of spreading and decelerating effluents depends in part of the rate deceleration of the plume (Wright and Nittrouer, 1995).
The positions along the Southern Brazilian inner Shelf highly influenced by the Patos Lagoon coastal plume tend to receive most contribution of the initial deposition of sediments occurring in short time scales. Thus, in order to investigate the variability of the spatial structure of the Patos Lagoon coastal plume an EOF analysis was carried out. The EOF analysis was performed over the salinity time series array obtained from the simulations carried out for 1998, considering the physical forcing all together. The temporal variability pattern of the EOF's is obtained through the spectral analysis of the expansion coefficient time series and compared to the energy spectra of the fluvial discharge and meridional and zonal wind components. The spectral analysis is performed with a fast Fourier transform (FFT) and the block averaging method is used to smooth the spectra in the frequency domain (Emery and Thomson, 1998) from two to six degrees of freedom.

\subsection{Remote sensing data}

Remote sensing data are used to qualitatively verify the response of the calculated coastal plume to the wind effect. The satellite images obtained from the MODerate-resolution imaging sepctroradiometer (MODIS) Aqua are compared with the wind conditions provided by the Reanalysis home page. The raw images were obtained from the NASA EOS Data Gateway (EDG) for September 13 and September 24, 2002 and processed to generate a true color image. MODIS data are stored as data granules ( $5 \mathrm{~min}$ time of data collection) in the HDF format. The MYD01 (Level 1A scans of raw radiances in counts) were ordered and downloaded via file transference protocol (ftp) software and the SeaWiFS Data Analysis System (SEADAS) was used to geolocate and generate the calibrated radiances file (Level 1B full swath at $250 \mathrm{~m}, 500 \mathrm{~m}$ and $1 \mathrm{~km}$ resolution) used to perform the true color image.

\section{Results and discussion}

\subsection{The response of the coastal plume to the main physical forcing}

In order to investigate the formation and behavior of the Patos Lagoon coastal plume, simulations were carried out for 180 days applying the physical parameters established in the verification of the model section. The simulated period is between January 1 and June 29 1998, which represents an anomalous river discharge year 
due to the El Niño phenomena. The set up of the first simulation started considering only the river discharge at the north of the lagoon and the Coriolis force. A second simulation added the contribution of the tides, and the last simulation the contribution of the winds.

The response of the coastal plume to the Earth rotation suggests that the freshwater reaching the coastal zone and subject to rotational effects (Fig. 7A) spreads over the shelf and turns anticyclonically towards the northward direction. This is coincident with the direction of propagation of the Kelvin wave in the Southern Hemisphere, contributing to the asymmetry of the circulation.

Csanady (1978) comments that a freshwater flux over the shelf can produce this type of response in the form of a trapped pressure field along the coast. Several authors observed that this trapped pressure field propagates in the same direction of the Kelvin wave propagation (Brink, 1991; Kourafalou et al., 1996a; Xia et al., 2007, among others). Studies carried out by Garvine (1987) and O'Donnel (1990), for example, show that the Connecticut River plume spreads from the mouth, being deflected towards the direction of Kelvin wave propagation (to the right in the Northern Hemisphere). They comment that this can be related to the Coriolis force and/or the along-shelf current. Xia et al. (2007) verified a similar behavior when studying the Cape Fear River plume without wind effects. Simionato et al. (2004) simulated the La Plata River coastal plume considering the freshwater discharge, and the Coriolis force, and also observed the northward transport of the coastal waters over the SBS, corroborating the results obtained in this study. The vertical profiles extracted inside the plume when considering only the Earth rotation show a welldistributed salinity pattern above the $5 \mathrm{~m}$ depth along (Fig. 7B) and towards (Fig. 7C) the coast, with weak salinity stratification observed in the horizontal and almost constant vertical stratification along and towards the coast.

The tidal effect was then considered in a second simulation by prescribing the main tidal components for the area in the oceanic boundary of the domain (Fig. 1B). Fig. 8A presents the calculated salinity and velocity fields, indicating that the Patos Lagoon coastal plume under tidal effects spreads longer over the shelf, reducing its superficial area and the horizontal salinity gradient in the cross-shore direction (Fig. 8C). The mixing process induced by the tides reduces the northeastward intrusion of the plume compared with the unrealistic situation forced only by the Coriolis force. These results suggest that it is essential to include the tidal effects to produce the expected plume structure and to represent the upstream intrusion of the brackish waters into the shelf. Chao (1990) and Garvine (1999) also observed the reduction of the salinity gradient, a further radial spreading and the increase of the superficial area of the plume under tidal effects.

The vertical structure of the coastal plume along the shelf after 180 days of simulation (Fig. 8B) presents an asymmetric structure, with a weak northward spreading tendency. The tidal currents generate a residual effect that increases the vertical circulation close the Patos Lagoon mouth promoting mixing and enhancing the brackish waters transportation alongshore. The tidal effect also contributes to the across-shore spreading of the plume, reducing the vertical stratification offshore and increasing onshore (Fig. 8C). The cross-shore circulation pattern induced by the tides alternates between upwelling and downwelling events, following the dominant period of the tides (diurnal cycle).

Zimmerman (1981) and Chao (1990) have shown that channels between shelf-estuary interaction are regions characterized by the
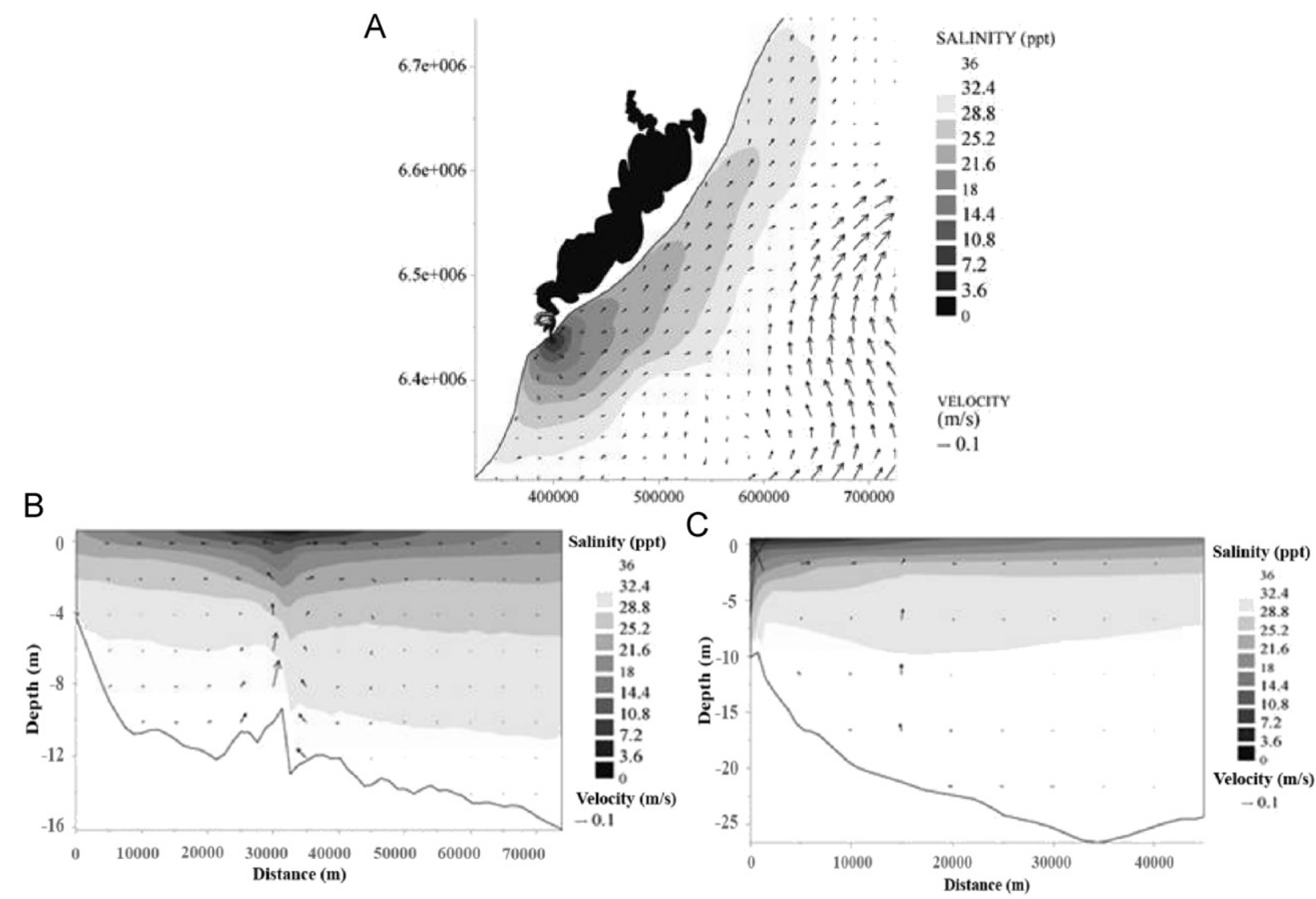

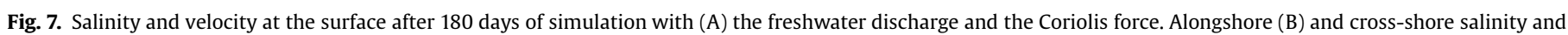
velocity profiles (C) after 180 days of simulation. In the vertical figures, the sigma levels are presented as equally spaced to improve the visualization. 


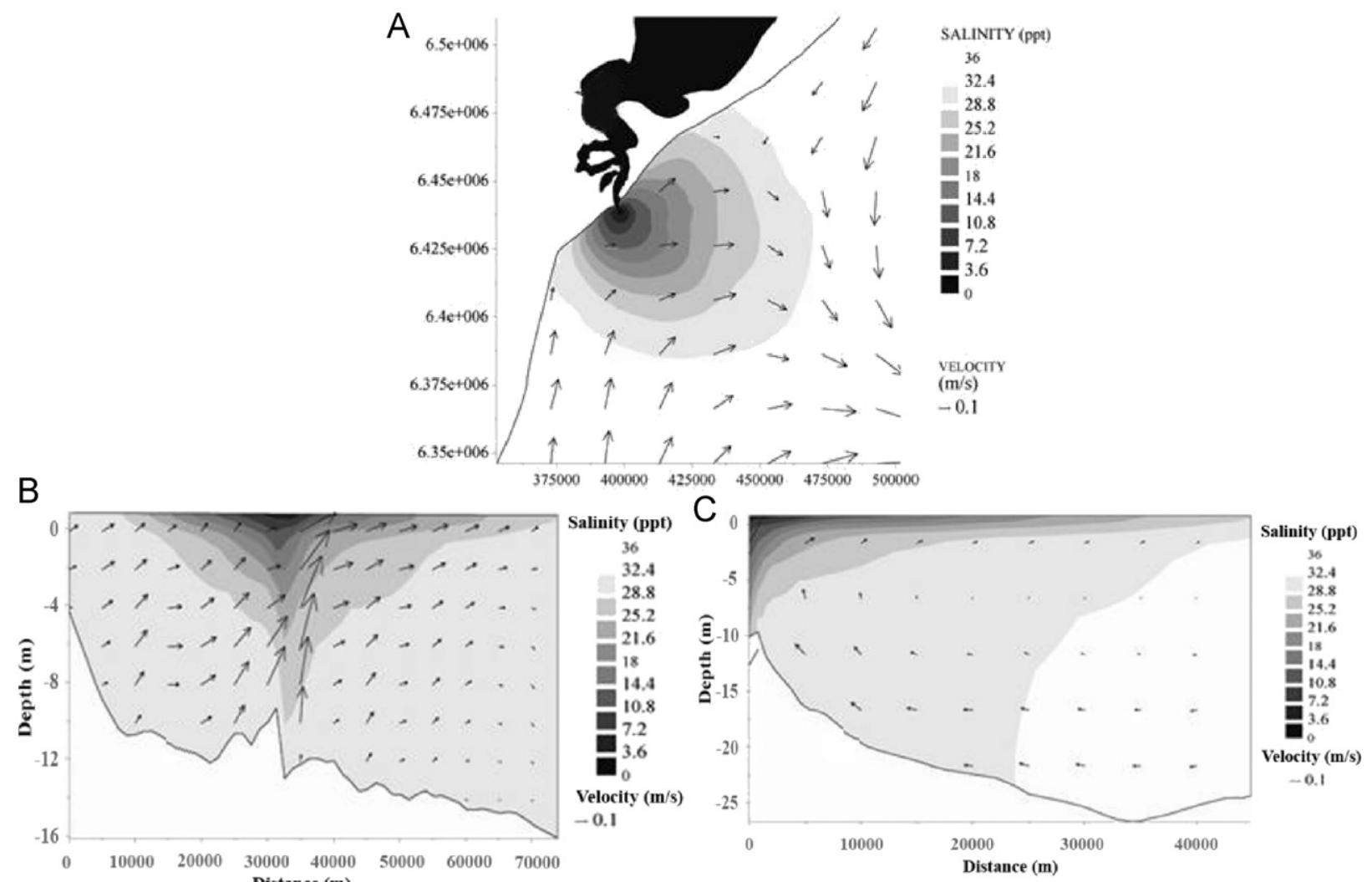

Fig. 8. Salinity and velocity fields at the surface (A). Alongshore (B) and cross-shore salinity and velocity profiles (C) after 180 days of simulation considering the Coriolis force and the tides. In the vertical figures, the sigma levels are presented as equally spaced to improve visualization.

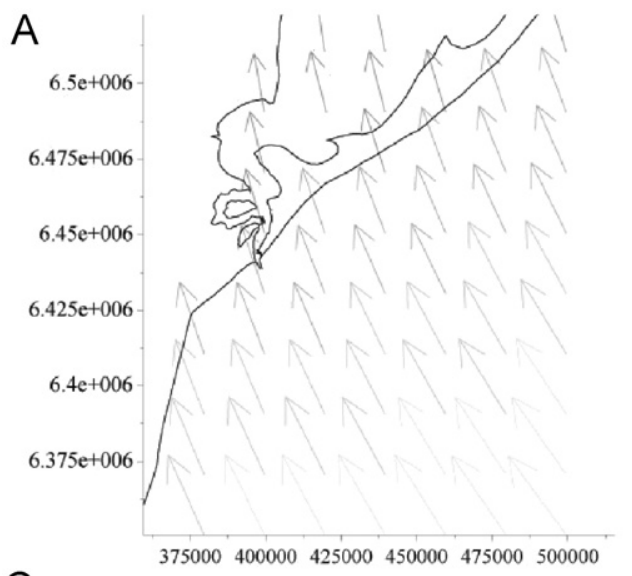

C

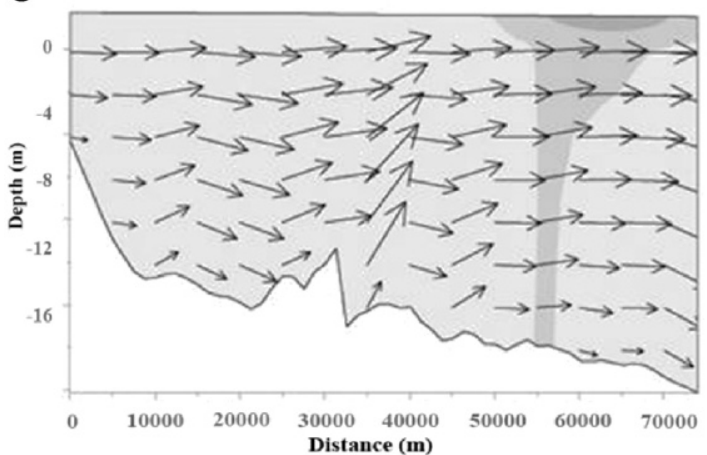

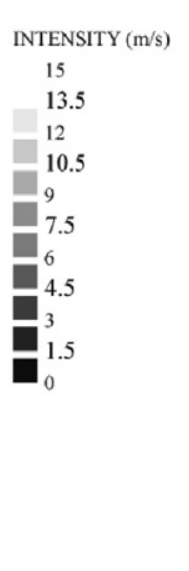

Salinity (ppt)

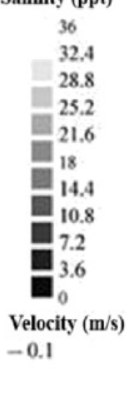

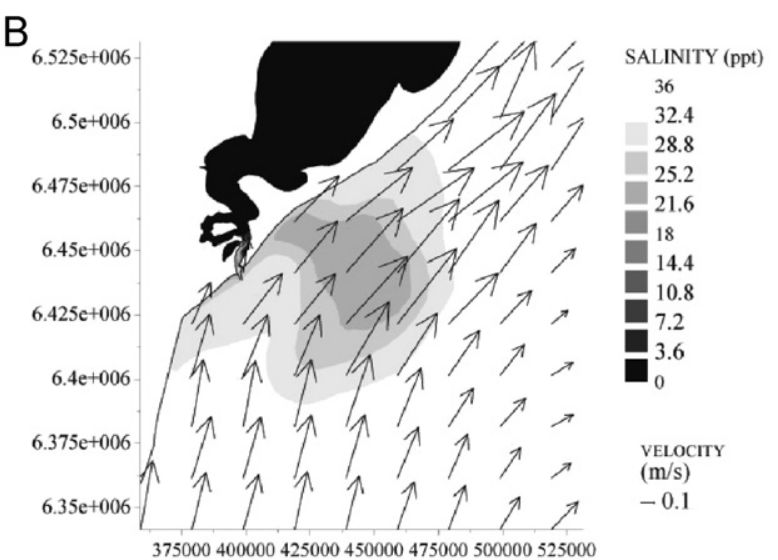

$\mathrm{D}$

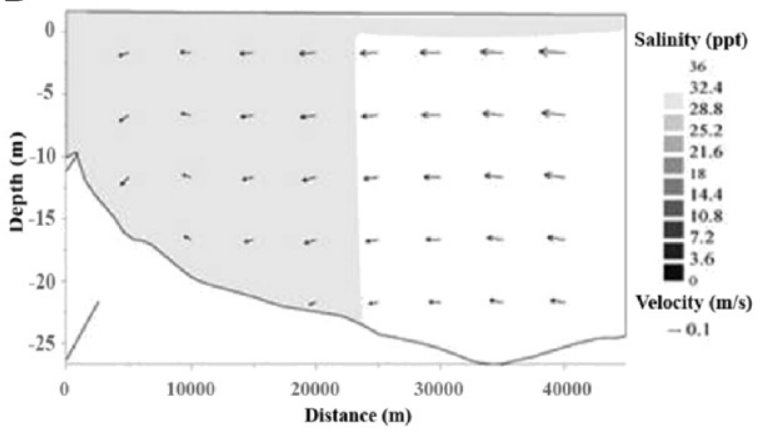

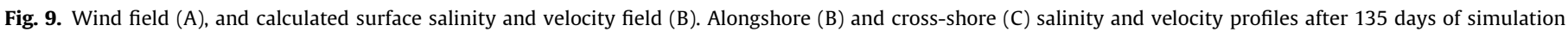
considering the Coriolis force, the tides and the winds. In the vertical profiles, the sigma levels are presented as equally spaced to improve visualization. 
nonlinear circulation and dominated by cyclonic and anti-cyclonic eddies at each of the channel sides, being controlled by the ebb/ flood regime. Chao (1990) comment that the Coriolis force can intensify the anti-cyclonic eddies contributing for the asymmetry generation. Several authors comment that the tidal action contributes to increase the mixing processes reducing salinity stratification (O'Donnel, 1990; Pritchard, 2000; Guo and ValleLevinson (2007), among others). Guo and Valle-Levinson (2007) verified that the tidal influence increases the mixing and weaken stratification close to the entrance of Chesapeake Bay, resulting in weaker vertical gradients.

After investigating the response of the Patos Lagoon coastal plume to rotation and tidal effects, simulations are carried out including the wind. Results indicate that the influence of southeasterly winds (Fig. 9A) induce the northeastward transportation of the plume (Fig. 9B). Under these conditions, the intensity of the vertical circulation is reduced, the horizontal advection is dominant and vertical well-mixed conditions are observed along (Fig. 9C) and towards (Fig. 9D) the coast. The spreading pattern previously observed for southeasterly winds (Fig. 9A), was enhanced by southwesterly wind conditions observed in the following day (Fig. 10A). These conditions maintain the horizontal circulation pattern and intensify the northeastward displacement of the plume and the mixing process along the coast (Fig. 10B). Thus, winds from the south quadrant enhance the horizontal advection maintaining the horizontal salinity gradients and the vertically well-mixed conditions alongshore (Fig. 10C) and acrossshore (Fig. 10D).

Chao (1988b) demonstrated through numerical modeling experiments that downwelling favorable winds contribute to elongate the plume alongshore. This author observed that downwelling wind conditions weakens and reverses the surface current, promoting the vertical mixing process and the destratification of the water column. Soares et al. (2007b) verified that downwelling favorable winds enhance the mixing process forming vertically well-mixed and narrow plumes. Xia et al. (2007) observed that the intensity of winds tend to reduce the surface plume size and distort the bulge shape due to enhanced windinduced surface mixing.

Further results also indicate that northeasterly winds (Fig. 11A) contribute to spreading the plume southwestward and offshore (Fig. 11B). The influence of the wind increase the vertical stratification close the Patos Lagoon mouth (Fig. 11C) inducing the displacement of the brackish waters alongshore. These wind conditions enhance the upwelling process (Fig. 11D) spreading the plume and intensifying the vertical stratification offshore. Northwesterly winds (Fig. 12A) contribute to spreading the plume offshore (Fig. 12B), reversing the previous superficial and alongshore circulation pattern. These conditions (Fig. 12C) induce an alongshore flux northwestward reducing the vertical stratification close the north of the Patos Lagoon mouth. These wind conditions enhance the mixing process (Fig. 12D) close to the coast, preventing the spreading of the plume offshore. Other modeling studies demonstrated that the plume becomes thinner and is advected offshore by the cross-shore Ekman transport induced by upwelling favorable winds (Chao, 1988b; Kourafalou et al., 1996a, b; Fong and Geyer, 2001; Soares et al., 2007b; Xia et al., 2007). Soares et al. (2007b) observed that upwelling favorable winds initially caused an increase of the vertical stratification due the offshore removal of the riverine waters. Fong and Geyer (2001) and Soares et al. (2007b) verified that thinned plumes present stronger vertical velocity shear in their front, promoting intense mixing and downward entrainment of the plume water, reducing stratification. Chao (1988b) observed that seaward winds enhance the vertical current shear and reduces the stratification of the water column from the surface downwards.

Results presented in this section indicate that the dynamic response of the Patos Lagoon coastal plume to the wind action
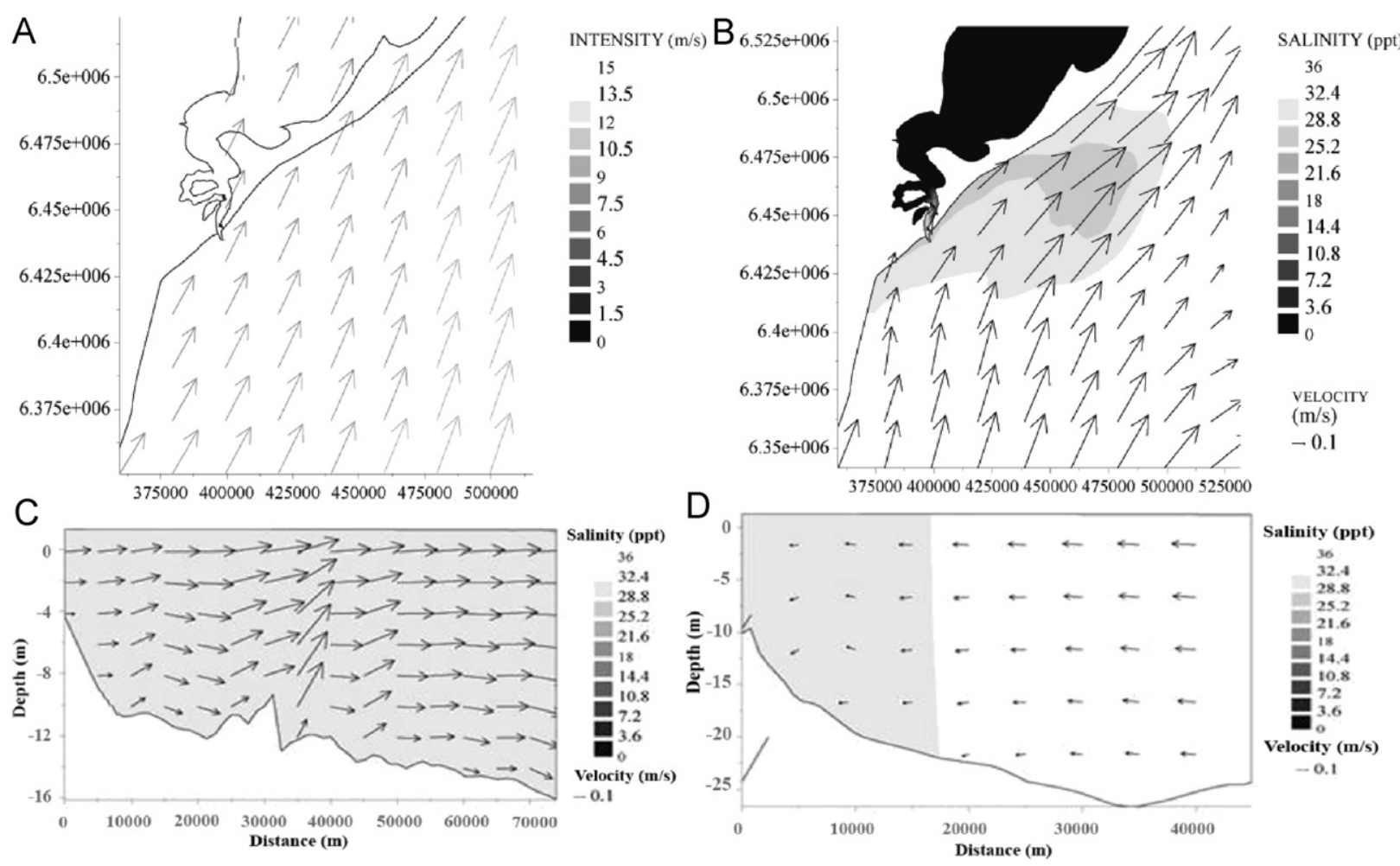

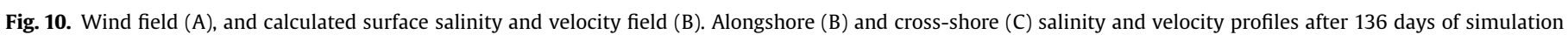
considering the Coriolis force, the tides and the winds. In the vertical figures, the sigma levels are presented as equally spaced to improve visualization. 

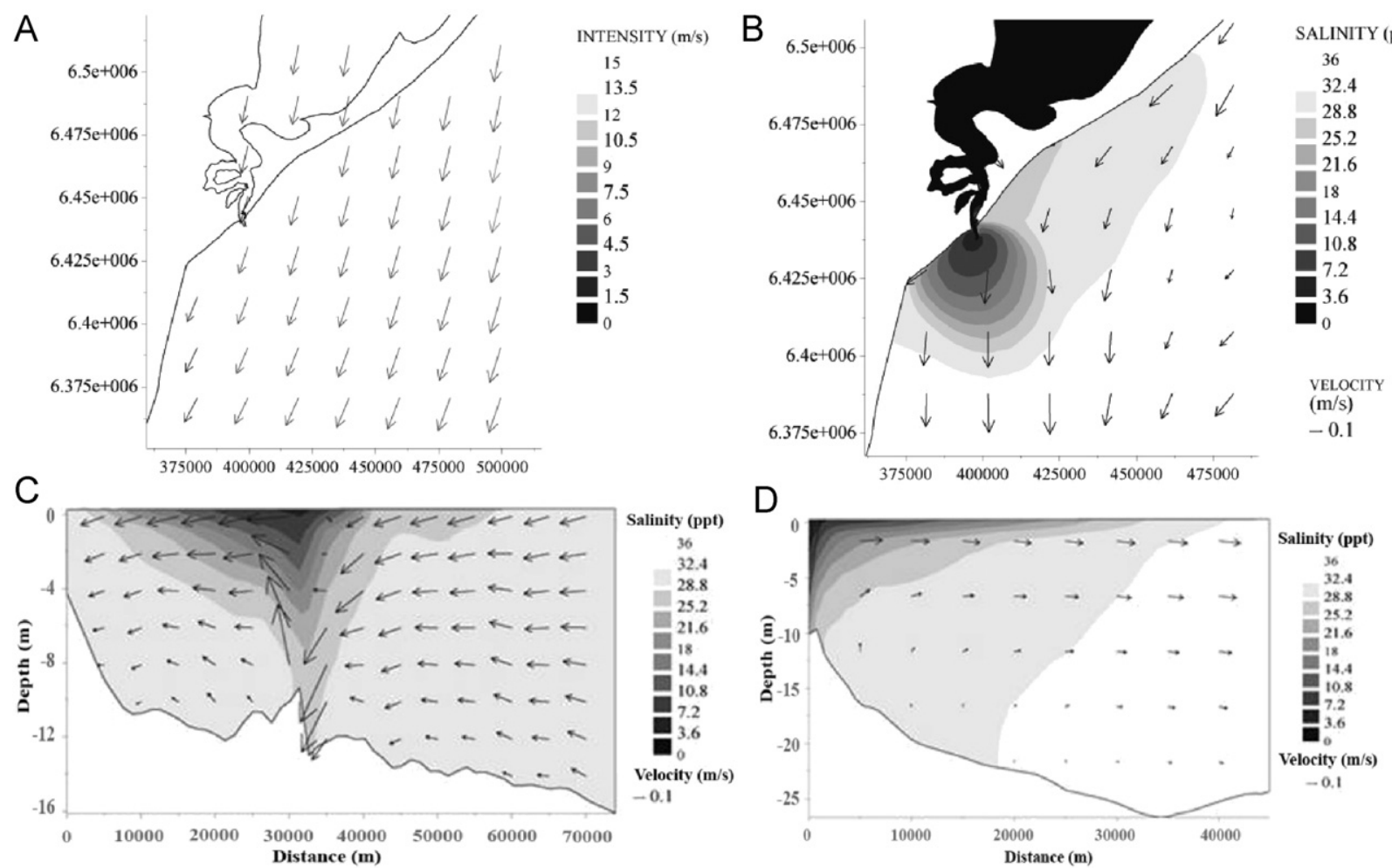

Fig. 11. Wind field (A), and calculated surface salinity and velocity field (B). Alongshore (B) and cross-shore (C) salinity and velocity profiles after 144 days of simulation considering the Coriolis force, the tides and the winds. In the vertical figures, the sigma levels are presented as equally spaced to improve visualization.
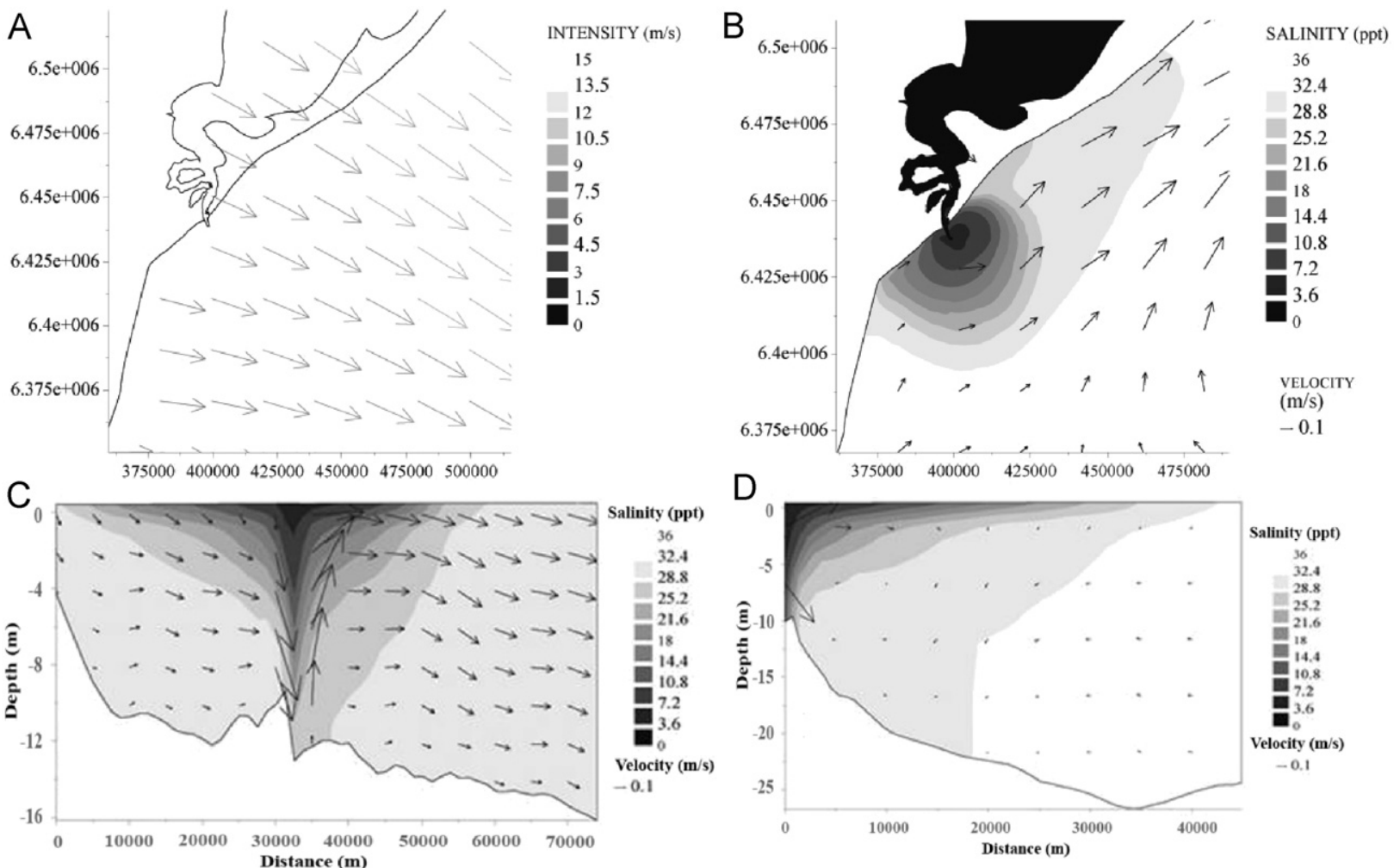

Fig. 12. Wind field (A), and calculated surface salinity and velocity field (B). Alongshore (B) and cross-shore (C) salinity and velocity profiles after 145 days of simulation considering the Coriolis force, the tides and the winds. In the vertical figures, the sigma levels are presented as equally spaced to improve visualization.

takes less than 1 day, and that moderated wind conditions can reverse the previous flow direction of the plume (Figs. 11B and 12B). Xia et al. (2007) also observed that moderated wind conditions can mechanically reverse the flow direction of the Cape Fear River plume. For the Patos Lagoon, southeasterly and southwesterly winds intensify the horizontal advection 
alongshore and across-shore. On the other hand, northeasterly and northwesterly wind conditions enhance the vertical circulation mainly close to the Patos Lagoon mouth. The results presented here suggest that the winds are the dominant forcing controlling the behavior and orientation of the Patos Lagoon coastal plume in synoptic time scales. Studies carried out by Zhang et al. (1987), Chao (1988b), Kourafalou et al. (1996a,b), Pritchard (2000), Warrick et al. (2007) and Xia et al. (2007) also observed that the prevailing wind direction controls the majority of alongshore transport affecting the direction and spatial structure of coastal plumes. The residual orientation of mean and large scale plumes can be controlled by dominant winds (Hickey et al., 1998; Cugier and Le Hir, 2002; Morey et al., 2003; Warrick et al., 2007). This section was focused in obtain information about the contribution of the principal forcing mechanism controlling the behavior of the Patos Lagoon coastal plume in synoptic time scales. The fate and behavior of plumes can be controlled for different mechanism forcing in different time scales. But the forcing that dominate the short-term spreading and mixing can differ significantly from those that determine the residual behavior, the long-term sediment transport and deposition patterns. Wright and Nittrouer (1995) present evidences of the differences in the plume direction when the dynamic process and the sediment transport are examined at different time scales for the Changjiang, Columbia and Purari systems.

Along the SBS the principal contribution of the La Plata river plume can be attributed to the residual transport northeastward along the continental shelf (Soares et al., 2007a,b; Piola et al., 2005). Therefore, the approximations used maintaining the salinity and temperature boundary conditions constant along the oceanic boundaries during all the simulations can be considered as the first approximation for the study of the Patos Lagoon coastal plume and their dynamics on the coastal region. Burrage et al. (2008) investigated the interaction of the Patos Lagoon coastal plume and the La Plata river plume in contrasting winter (2003) and summer (2005) conditions. These authors verified that the La Plata plume has highly asymmetric with along-shelf development towards the north and it behaved dynamically like a buoyant coastal boundary current, with an approximately geostrophic across-shelf momentum balance, on the other hand, the Patos Lagoon coastal plume maintained its integrity as a relatively symmetric, ageostrophic, frictionally dominated plume with significant across-shelf, and modest along-shelf, development.
Furthermore, during El Niño years the freshwater discharge pattern in the southern Brazil can be intensified due to positive precipitation anomalies associated to these climatic events (Grimm et al., 1998, 2000). The high precipitation over South America and the northeasterly anomalies over the southwestern Atlantic are related to the intensification of the western portion of the South Atlantic high-pressure center (Barros et al., 2002; Silvestri, 2004). Thus, as the volume of freshwater discharged by the Patos Lagoon tributaries is essential for the plume formation, it is expected that the intensity of the precipitation and river discharge during the year 1998 contributed to the large dimension of the observed coastal plume. During normal situations, the austral summer and fall in the study region usually present low freshwater discharge, which contributes for the formation of small coastal plumes under small influence of the Coriolis force. However, these structures tend to be highly nonlinear, and present sharp frontal boundaries and internal hydraulic jumps (Garvine, 1995).

\subsection{The formation of the Patos Lagoon coastal plume}

The investigation of the main physical forcing controlling the formation of the Patos Lagoon coastal plume was carried out through an EOF analysis of the calculated salinity at the transversal profile located at the mouth of the estuary (Fig. 1C). The EOF analysis indicates that the first empirical mode explains $93 \%$ of all the salinity variability at the mouth of the estuary. The first EOF mode (Fig. 13) indicates an intense shear zone along the main channel, covering the first $10 \mathrm{~m}$ of depth. That shear region suggests the presence of dominant ebb conditions during the simulation period. The cross spectral analysis (not presented) between the time series of the expansion coefficient and the fluvial discharge confirms the principal mode of oscillation following a quasi-monthly cycle of 32 days.

The EOF analysis suggests that the intensity of the fluvial discharge controls the formation of the Patos Lagoon coastal plume. The analysis of the vertically integrated discharge at the mouth of the estuary (Fig. 14A) indicates ebb events occurring for longer periods than flood events. Normally, during longer periods of discharge (negative values) the salinity reaches minimum values (Fig. 14B) and the south quadrant winds (Fig. 14C) do not reverse the ebb conditions (Fig. 14A).

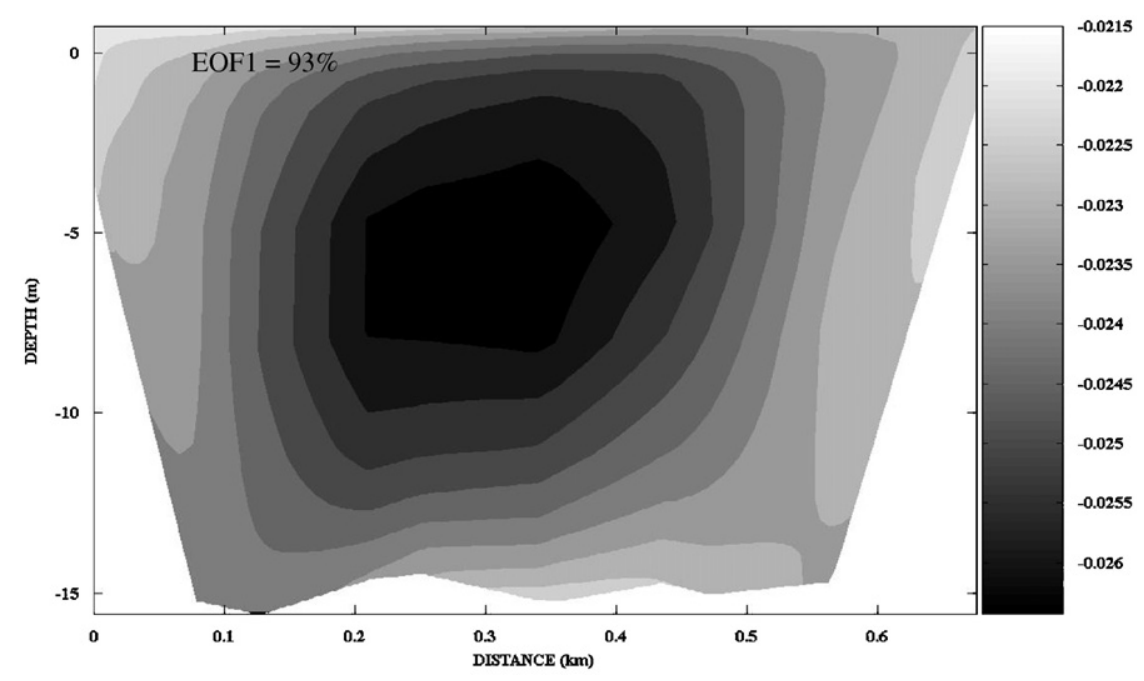

Fig. 13. The first EOF mode. The percentage of variance is presented on the top left. 


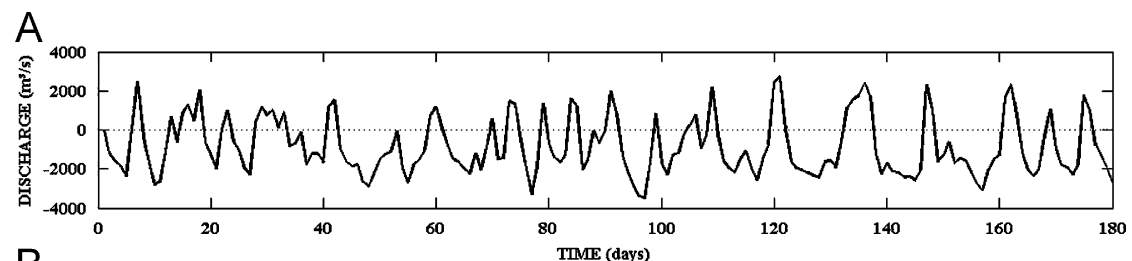

B

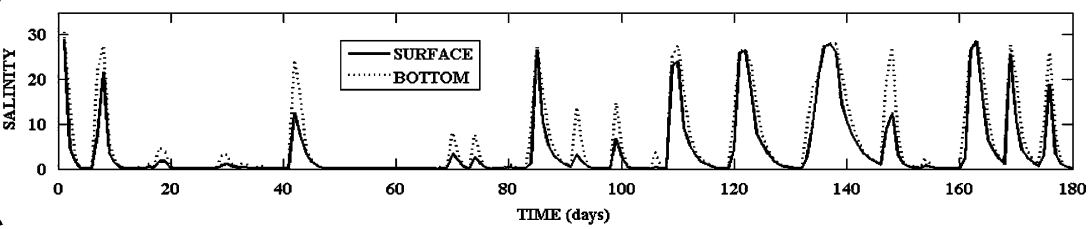

C

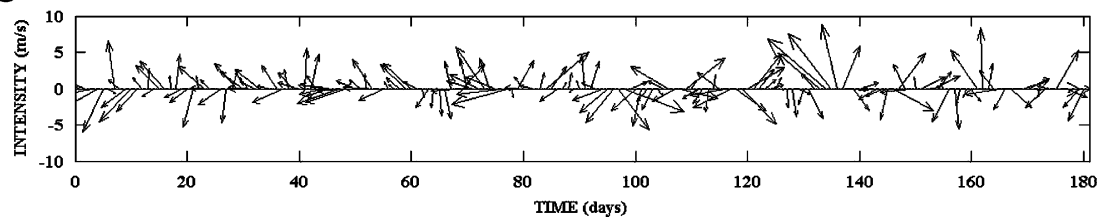

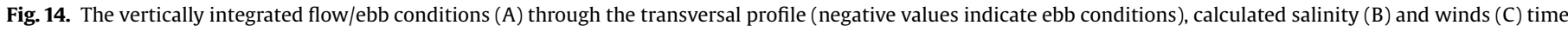
series (positive winds comes from the south quadrant) from January 1 to June 29, 1998.
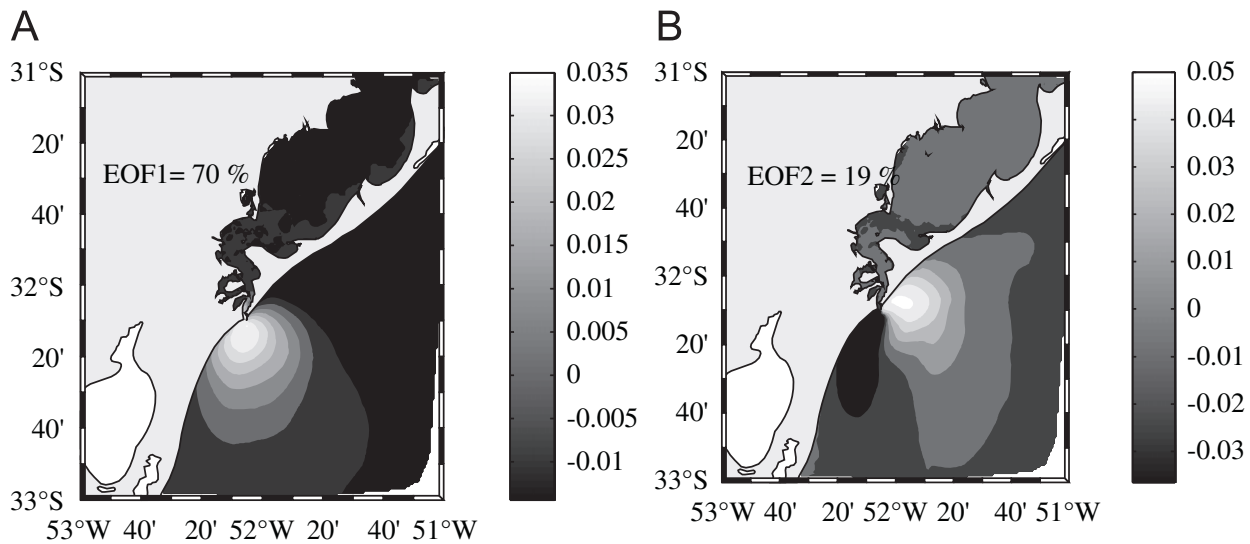

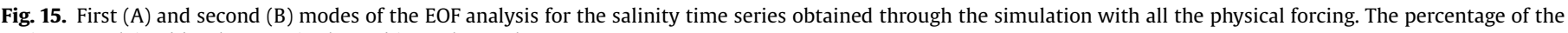
variance explained by that EOF is showed in each panel.

\subsection{Spatial and temporal variability of the Patos Lagoon coastal plume}

A spectral analysis of the time series of river discharge (not presented) indicates that in timescales smaller than 180 days, the main variability of the Patos Lagoon coastal plume follows a monthly timescale (36 days). The meridional wind component influences the region in a well-defined band of variability at synoptic time scales (13 days), while the zonal component act on a wider band of frequency, between 6 and 25 days.

Fig. 15 presents results from the two main empirical modes. The first EOF (Fig. 15A) explains $70 \%$ of the plume variability, reflecting the dominant migration southwestward of the plume along the coastal zone, following the coastline orientation. The second EOF mode explains around 19\% of the plume variability and indicates two distinct areas: one with intense shear and another with a moderate shear located towards the northern and the southern portion of the mouth, respectively (Fig. 15B). The spectral analysis (not presented) suggests that the principal mode of oscillation follows a synoptic cycle of 13 days and the second mode appears as a combination of two cycles of 7 and 25 days.
The EOF analysis confirms that the winds control almost $90 \%$ of the variance of the Patos Lagoon coastal plume over the inner continental shelf in synoptic time scales. The principal mode shows the prevailing condition of the plume over the shelf being controlled by the meridional wind component (north/south). The alternated migration of the plume northwestward along the continental shelf reflects less than $20 \%$ of the variance and is controlled by the zonal wind component (east/west) at times scales ranging between 7 and 25 days. Thus, the dominance of north quadrant winds over the study region contributes to the prevailing southwestward migration pattern of the plume, while the passage of frontal systems over the area tend to transport the brackish waters to the north of the Patos Lagoon mouth.

The Patos Lagoon discharge represents an important local contribution to the nutrient and suspended sediments budget of the Southern Brazilian Inner Shelf. There are evidences of problems with deposition of cohesive sediments along the Cassino beach, south of the Patos Lagoon mouth recorded since 1973 (Martins et al., 1979). Recent data obtained between 2004 and 2005 (Sperle et al., 2005; Calliari et al., 2005) using echobathymetry, seismic reflection, grab and core sampling allowed the detailed mapping of the fluid and more compacted mud between 
the isobaths of 5 and $12 \mathrm{~m}$ in an area where the deposits were not mapped yet. The results presented in this section suggest the dominant direction of propagation of the Patos Lagoon coastal plume in synoptic time scales is compatible with the position of the cohesive sediment deposit observed to the south.

The EOF analysis of the vertical salinity profiles (not presented) confirms the existence of a dominant maximum of variability towards the south of the Patos Lagoon and across-shore controlled by the wind action and following cycles of 13 days. These variability modes indicate a high variability region $35 \mathrm{~km}$ southwestward and $40 \mathrm{~km}$ offshore, which is strongly influenced by the Patos Lagoon coastal plume.

Several studies using time series analysis and numerical simulations (Möller, 1996; Möller et al., 1996, 2001; Fernandes, 2001; Fernandes et al., 2002, 2004; Castelão and Möller, 2006) have shown that the Patos lagoon circulation pattern itself, the mixing and exchange process during low and mean discharge conditions are controlled by the wind effect at synoptic times scales coincident with the passage of meteorological systems every 3-17 days.

\subsection{Remote sensing data $x$ wind forcing (September 2002)}

The results of the numerical modeling experiments indicate the winds as the main physical forcing controlling the behavior of the Patos Lagoon Coastal plume in synoptic timescales. In order to corroborate that effect, the true color images obtained from the
MODIS aqua sensor are qualitatively compared with wind data from reanalysis for the same period.

The southwesterly wind conditions (Fig. 16A) observed in September 13 is associated to the influence of the passage of frontal systems over the study region. These wind conditions along the SBS induce the occurrence of downwelling in the water column. In response to these, the Patos Lagoon coastal plume spreads northeastward close to the coastline (Fig. 16B).

The second situation (September 24) presents a period of transition between the southwesterly and northwesterly winds, indicating the reversal of the wind direction when after the passage of the frontal system (Fig. 16C). These wind conditions contribute to the transportation of continental waters toward the ocean and to enhance the re-suspension process along the shallow areas. During these conditions, the coastal plume detaches from the coast, being transported southeastward towards the ocean (Fig. 16D).

Thus, the satellite images show two different situations which highlight the contribution of the winds for the dynamics of the Patos Lagoon coastal plume in synoptic timescales. Furthermore, this qualitative analysis of the images suggests that re-suspension process might be important as moving towards the shore

\section{Conclusions}

Modeling results from 180 days of simulation for the SBS indicate the influence of rotation (Coriolis), tidal and wind effects
A

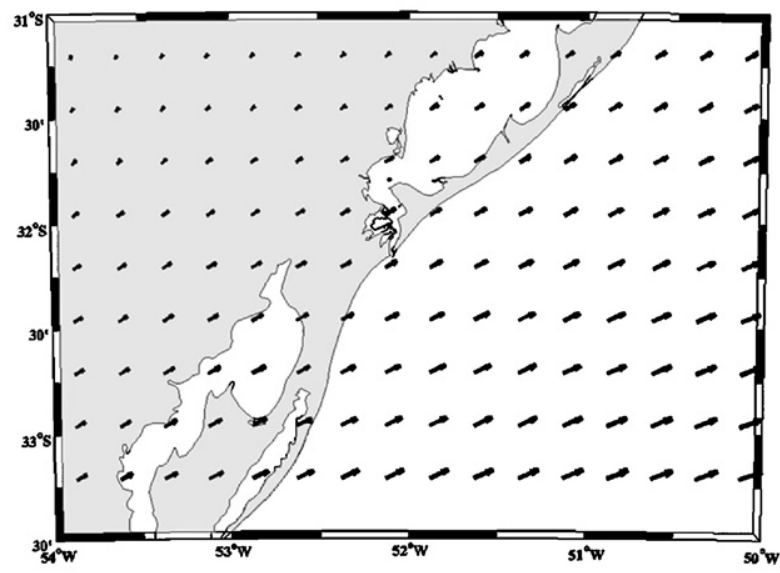

C

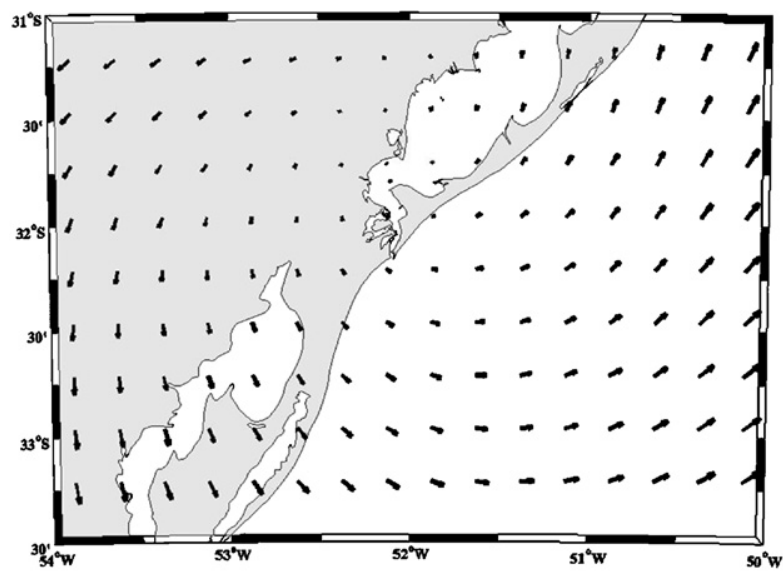

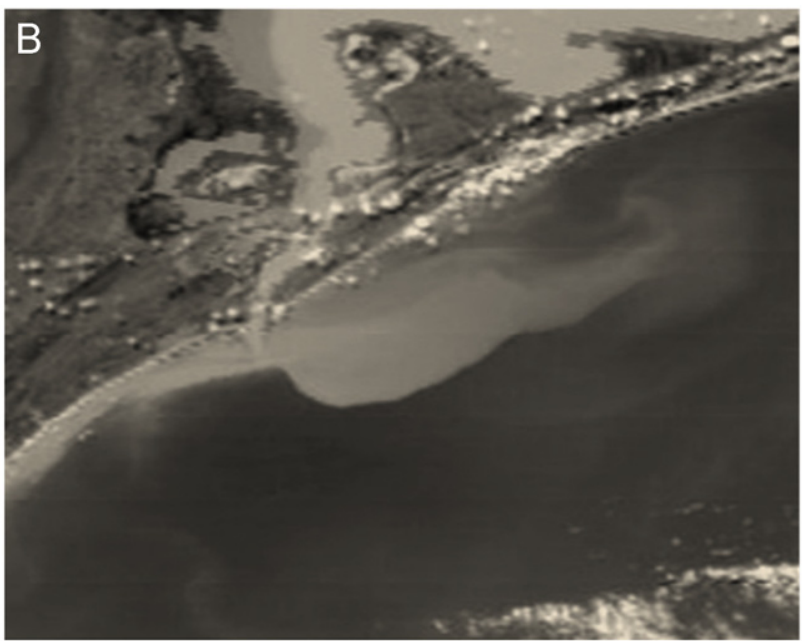

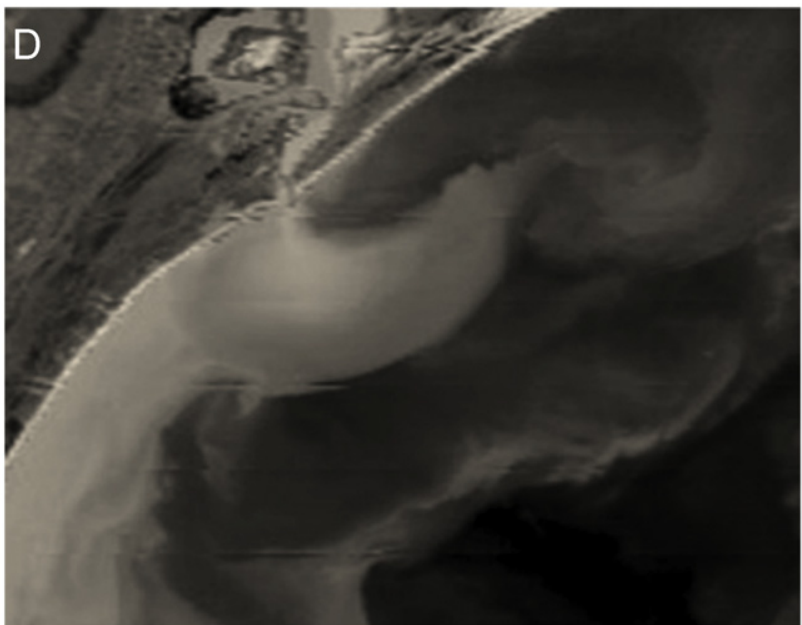

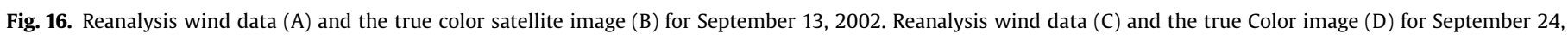
2002. 
for the formation and behavior of the Patos Lagoon plume. The main conclusions of this study were:

- The coastal plume under rotational effects only spreads over the shelf turning northward anti-cyclonically (in the Kelvin wave direction). The weak current velocity contributes to weak horizontal salinity stratification and a vertical stratification almost constant along and towards the coast. This forcing acting alone induces an unexpected northwestward propagation pattern of the plume.

- The tidal effects are important for a realistic representation of the plume propagation along the coast. Their effects intensify the horizontal and vertical mixing process, spreading the freshwater over the shelf. The tides contribute to the northward transportation of the plume, but it prevents the excessive propagation observed when the Coriolis force is considered alone.

- The wind effect figures as the main mechanism controlling the behavior of the Patos Lagoon coastal plume over the inner SBS in synoptic time scales. The response time to the wind action occurs in less than 1 day and winds of moderate intensity can mechanically reverse the plume orientation.

- The influences of southeasterly and southwesterly winds contribute to the northeastward transportation of the plume increasing the horizontal circulation pattern and enhancing the horizontal and the vertical mixing process. These winds conditions contribute to the vertical destratification of the inner continental shelf.

- The influence of northeasterly and northwesterly winds favor ebb conditions in the Patos Lagoon and contributes to the southwestward and southeastward transportation of the plume, respectively. These wind conditions contribute to spreading the brackish waters offshore, increasing the vertical stratification of the oceanic waters. These wind conditions intensify the vertical circulation mainly close the Patos Lagoon mouth.

- The intensity of the river discharge on the northern boundary of the Patos Lagoon controls the ebb conditions (93\% of the variance) at the mouth of the estuary. Longer periods of ebb flow higher than $2000 \mathrm{~m}^{3} \mathrm{~s}^{-1}$ can prevent the wind action hindering the introduction of marine waters on the south part of the estuarine region and contributes to the coastal plume formation.

- There are two main superficial variability modes of the plume. The first mode (explaining $70 \%$ of the variability) was associated to the plume transportation southwestward and the second mode (explaining 19\% of the variability) was associated to the intermittent migration of the plume northeastward. Both variability modes are controlled by the winds and the dominance of north quadrant winds over the study region contribute to the prevailing southwestward migration pattern of the plume, while the frontal system passage tend to transport the brackish waters to the north of the Patos Lagoon mouth.

- El Niño years intensify the freshwater discharge over the study region, contributing for the formation of large scale rotational plumes. During normal years, these freshwater conditions and large scale plumes can be expected during winter and spring months.

\section{Acknowledgements}

The authors are grateful to Conselho Nacional de Pesquisa $e$ Desenvolvimento $(\mathrm{CNPq})$ for sponsoring this research under Contract 590006/2005-3. Further acknowledgements go to the
Brazilian Navy for providing detailed bathymetric data for the coastal area, to the Brazilian National Water Agency (ANA) and the National Oceanic \& Atmospheric Administration (NOAA) for supplying the fluvial discharge and wind data sets, respectively, and to the HR Wallingford to providing the academic license of the TELEMAC System to accomplish this work.

\section{References}

Barros, V.R., Grimm, A.M., Doyle, M.E., 2002. Relationship between temperature and circulation in southeastern South America and its influence from El Niño and La Niña events. Journal of Meteorological Society 80, 21-32.

Blaas, M., Dong, C., Marchesiello, P., McWilliams, J.C., Stolzenbach, K.D., 2007. Sediment-transport modeling on Southern Californian shelves: A ROMS case study. Continental Shelf Research 27, 832-853.

Blanton, J.O., 1981. Ocean currents along a nearshore zone on the Continental Shelf of the Southeastern United States. Journal of Physical Oceanography 11, 1627-1637.

Brink, K.H., 1991. Coastal-trapped waves and wind-driven currents over the continental shelf. Annual Reviews Fluid Mechanics 23, 389-412.

Burrage, D., Wesson, J., Martinez, C., Pérez, T., Möller Jr, O., Piola, A., 2008. Patos Lagoon outflow within the Rió de la Plata plume using an airborne salinity mapper: observing an embedded plume. Continental Shelf Research 28 $1625-1638$.

Calliari, L.J., Holland, T., Sperle, M.S. D., Vinzon, S., Thorton, E.D., Stanton, T.P., 2005 Experimento Cassino 2005: Uma sintese dos levantamentos efetuados na antepraia e zona de arrebentação. Boletim de Resumos da X ABEQUA, Guarapari, ES. p. 107.

Castelão, R.M., Möller, O.O., 2006. A modeling study of Patos Lagoon (Brazil) flow response to idealized Wind and river discharge: dynamical analysis. Brazilian Journal of Oceanography 54 (1), 1-17.

Castello, J., Duarte, A., Möller, O. O., Niencheski, F., Odebredcht, C., Weiss, G., Habiaga, R., Bellotto, V., Kitzmann, D., Souto, C., Souza, R., Ciotti, A., Fillmann, G., Schwingell, P., Bersano, J., Cirano, M., Freire, K., Lima, I., Mello, R., Monteiro A., Resgalla, C., Soares, I., Suzuki, M., 1990. On the importance of coastal and subantartic waters for the shelf ecosystem off Rio Grande do Sul. Anais do Il Simpósio de Estrutura, Função e Manejo e Ecossistemas da Costa Sul e Sudeste, São Paulo, Brazil, pp. 112-129.

Castro, B., Miranda, L.B., 1998. Physical Oceanography of the western Atlantic continental shelf between $4 \mathrm{~N}$ and $34^{\circ} \mathrm{S}$. In: Brink, K., Robinson, A. (Eds.), The Sea-The Global Coastal Oceans, Vol. 10. Wiley, Newyork, pp. 209-251 (Chapter 8).

Ciotti, A.M., Odebrecht, C., Fillmann, G., Möller, O.O., 1995. Freshwater outflow and subtropical convergence influence on phytoplankton biomass on the southern Brazilian continental shelf. Continental Shelf Research 15 (14), 1737-1756.

Chao, S-Y., 1988a. River-forced Estuarine plumes. Journal of Physical Oceanography $18,72-88$.

Chao, S.-Y., 1988b. Wind-driven motion of Estuarine plumes. Journal of Physical Oceanography 18, 1144-1166.

Chao, S.-Y., 1990. Tidal modulation by estuarine plumes. Journal of Physical Oceanography 20, 1115-1123.

Chao, S-Y., Boicourt, W.C., 1986. Onset of estuarine plumes. Journal of Physical Oceanography 16, 2137-2149.

Chapman, D.C., Lentz, S.T., 1993. Trapping of a coastal density front by the bottom boundary layer. Journal of Physical Oceanography 24, 1464-1479.

Csanady, G.T., 1978. The arrested topographic wave. Journal of Physical Oceanography 8, 47-62.

Cugier, P., Le Hir, P., 2002. Development of a 3D hydrodynamic model for coastal ecosystem modeling. Application to the plume of the Seine river (France). Estuarine, Coastal and Shelf Science 55, 673-695.

Dinnel, S.P., Schroeder, W.W., Wiseman Jr., W.J., 1990. Estuarine-shelf exchange using Landsat images of Discharge plumes. Journal of Coastal Research 6 (4) 789-799.

Emery, W.J., Thomson, R.E., 1998. Data Analysis Methods In Physical Oceanography, Second and Revised ed. Elsevier, Amsterdam.

Fernandes, E.H.L., 2001. Modelling the hydrodynamics of the Patos Lagoon, Brazil. DSc. Thesis, Institute of Marine Studies Faculty of Science, University of Plymouth, England.

Fernandes, E.H.L., Dyer, K.R., Niencheski, L.F.H., 2001. TELEMAC-2D calibration and validation to the hydrodynamics of the Patos Lagoon (Brazil). Journal of Coastal Research 34, 470-488.

Fernandes, E.H.L., Dyer, K.R., Möller, O.O., Niencheski, L.F.H., 2002. The Patos Lagoon hydrodynamics during an El Niño event (1998). Continental Shelf Research 22, 1699-1713.

Fernandes, E.H.L., Mariño-Tapia, I., Dyer, K.R., Möller, O.O., 2004. The attenuation of tidal and subtidal oscillations in the Patos Lagoon estuary. Ocean Dynamics 54, 348-359.

Fernandes, E.H.L., Dyer, K.R., Möller, O.O., 2005. Spatial gradients in the flow of Southern Patos Lagoon. Journal of Coastal Research 20, 102-112.

Fong, D.A., Geyer, W.R., 2001. Response of a river plume during an upwelling favorable wind event. Journal of Geophysical Research 106 (C1), 1067-1084.

Fong, D.A., Geyer, W.R., 2002. The Alongshore transport of freshwater in a surfacetrapped river plume. Journal of Physical Oceanography 32, 957-972. 
Framiñan, M.B., Brown, O.B., 1996. Study of the La Plata turbity front, Part I: spatial and temporal distribution. Continental Shelf Research 16 (10), 1259-1282.

Garvine, R., 1981. Frontal jump conditions for models of shallow buoyant surface layer hydromechanics. Tellus 33, 301-312.

Garvine, R., 1982. A steady state model for buoyant surface plumes in coastal waters. Tellus 34, 293-306.

Garvine, R.W., 1987. Estuary plumes and fronts in shelf waters: a layer model. Journal of Physical Oceanography 17, 1877-1896.

Garvine, R., 1995. A dynamical system for classifying buoyant coastal discharges. Continental Shelf Research 15 (15), 1585-1595.

Garvine, R., 1999. Penetration of buoyant coastal discharge onto the continental shelf: a numerical model experiment. Journal of Physical Oceanography 29 , 1892-1909.

Garvine, R.W., Monk, J.D., 1974. Frontal structure of a river Plume. Journal of Geophysical Research 79 (15), 2251-2259.

Gelfenbaum, G., Stumpf, R.P., 1993. Observations of currents and density structure across a buoyant plume front. Estuaries 16 (1), 40-52.

Geyer, W.R., Hill, P.S., Kineke, G.C., 2004. The transport, transformation and dispersal of sediment by buoyant coastal flows. Continental Shelf Research 24 (7-8), 927-949.

Ghisolfi, R., 2001. Oceanic fronts off the Southern Brazilian coast. PhD. Thesis, University of New South Wales-School of Mathematics. New South Wales, Australia, unpublished.

Grimm, A.M., Ferraz, S.E.T., Julio, G., 1998. Precipitation anomalies in southern Brazil associated with El Niño and La Niña events. American Meteorological Society $11,2863-2879$

Grimm, A.M., Barros, V.R., Doyle, M.E., 2000. Climate variability in southern South America associated with El Niño and La Niña events. American Meteorological Society 13 (1), 35-58.

Guerrero, R.A., Acha, E.M., Framiñan, M.B., Lasta, C.A., 1997. Physical oceanography of the Rio de La Plata estuary, Argentina. Continental Shelf Research 17 (7), 727-742.

Guo, X., Valle-Levinson, A., 2007. Tidal effects on estuarine circulation and outflow plume in the Chesapeake Bay. Continental Shelf Research 27, 20-42.

Hartmann, C., Silva, O.F., 1989. Dinâmica sazonal da pluma de sedimentos da desembocadura da Laguna dos Patos, analisada através de imagens Landsat. Simpósio Brasileiro de Sensoriamento Remoto 4, Natal, Rio Grande do Norte, Brazil.

Hervouet, J.-M., 2007. Free Surface Flows: Modelling With the Finite Element Methods. Wiley, England (Copyright (2007).

Hickey, B.M., Pietrafesa, L.J., Jay, D.A., Boicourt, W.C., 1998. The Columbia rive plume study: subtidal variability in the velocity and salinity fields. Journal of Geophysical Research 103 (C5), 10339-10368.

Hutchinson, S.E., Sklar, F.H., Roberts, C., 1995. Short term sediment dynamics in a southeastern USA spartina marsh. Journal of Coastal Research 11, 370-380.

Kourafalou, V.H., Oey, L.Y., Wang, J.D., Lee, T.N., 1996a. The fate of river discharge on the continental shelf 1 : modeling the river plume and the inner shelf coastal current. Journal of Geophysical Research 101 (C2), 3415-3434.

Kourafalou, V.H., Lee, T.N., Oey, L.Y., Wang, J.D., 1996b. The fate of river discharge on the continental shelf 2 : transport of coastal low-salinity waters under realistic wind and tidal forcing. Journal of Geophysical Research 101 (C2) 3435-3455.

Mann, K.H., Lazier, J.R.N., 1991. Dynamics of marine ecosystems: Biological-Physical interactions in the Oceans. In: Blackwell Scientific Publications, Inc. Boston.

Marques, W.C., 2005. Padrões de variabilidade temporal nas forçantes da circulaç ão e seus efeitos na dinâmica da Lagoa dos Patos, Brasil. Master's thesis, University of Rio Grande, Rio Grande do Sul, Brasil, unpublished.

Martins, L.R., Melo, U., França, A.M.C., Santan, L., Martins, I.R., 1979. Distribuição Faciológica da Margem Continental Sul-rio-grandense. In: Congresso Brasileiro de Geologia, 260. Anais... Belém: SBG, v. 2, p. 115-132.

Möller, O.O., 1996. Hydrodinamique de La Lagune dos Patos, Mésures et Modelisation. DSc. Thesis, Université Bordeaux I, France.

Möller, O.O., Lorenzzetti, J.A., Stech, J.L., Mata, M.M., 1996. The Patos Lagoon summertime circulation and dynamics. Coastal Shelf Research 16, 335-351.

Möller, O.O., Castaing, P., Salomon, J.C., Lazure, P., 2001. The influence of local and non-local forcing effects on the subtidal circulation of Patos Lagoon. Estuarios 24, 297-311.
Morey, S.L., Martin, P.J., O’Brien, J.J., Wallcraft, A.A., Zavala-Hidalgo, J., 2003. Export pathways for river discharged fresh water in the northern Gulf of Mexico. Journal of Geophysical Research 108 (C10), 3303-3318.

Odebrecht, C., Garcia, V.M.T., 1996. Pytoplankton. In: Seeliger, U., Odebrecht, C., Castello, J.P. (Eds.), Subtropical Convergente Environments, The Coast and Sea in the Southwestern Atlantic. Springer, Berlin, pp. 183-196.

O'Donnel, J., 1990. The formation and fate of a river plume: a numerical model. Journal of Physical Oceanography 20, 551.

O'Donnel, J., Garvine, R.W., 1983. A time dependent, two layer frontal model of buoyant plume dynamics. Tellus 35, 73-569.

Piola, A., Rivas, A., 1997. Corrientes en La Plataforma Continental. In: Boschi, E. (Eds.), El Mar Argentino e sus Recursos Pesqueros, INIDEP, volume I, pp. 119-132.

Piola, A.R., Matano, R.P., Palma, E.D., Möller, O.O., Campos, E.J.D., 2005. The influence of the Plata River discharge on the western South Atlantic shelf. Geophysical Research Letters 32.

Pritchard, M., 2000. Dynamics of a small tidal Estuarine plume. PhD Thesis. University of Plymouth, Institute of Marine Studies Faculty of Science, Plymouth, United Kingdom, unpublished.

Rodi, W., 1984. Turbulence models and their applications in hydraulics. A state of the art review. Edition AIRH.

Royer, L., Emery, W.J., 1985. Computer simulations of the Fraser River plume. Journal of Marine Research 43, 289-306.

Silvestri, G.E., 2004. El Niño signal variability in the precipitation over southeastern South America during austral summer. Geophysical Research Letters 31, L18206.

Simionato, C.G., Dragani, W., Meccia, V., Nuñez, M., 2004. A numerical study of the barotropic circulation of the Río de la Plata estuary: sensivity to bathymetry, the Earth's rotation and low frequency wind variability. Estuarine, Coastal and Shelf Science 61, 261-274.

Simionato, C.G., Meccia, V.L., Dragani, W.C., Nuñez, M.N., 2006. On the use of the NCEP/NCAR surface winds for modeling barotropic circulation in the Rio de La Plata estuary. Estuarine, Coastal and Shelf Science 70, 195-206.

Smagorinski, J., 1963. General circulation experiments with the primitive equation, I. The basic experiment. Weather Review 91, 99-164.

Soares, I.D., Kourafalou, V., Lee, T.N., 2007a. Circulation on the western South Atlantic continental shelf. Part 1: Numerical process studies on Buoyancy. Journal of Geophysical Research 112, C04002.

Soares, I.D., Kourafalou, V., Lee, T.N., 2007b. Circulation on the western South Atlantic continental shelf. Part 2: Spring and autumn realistic simulations. Journal of Geophysical Research 112, C04003.

Sperle, M., Vinzon, S., Calliari, L.J., Rech, M., Fabri, J.B., Bispo, L., 2005. Aplicação de métodos geofísicos na avaliação da ocorrência de lamas fluidas na praia do Cassino, Rio Grande. II Congresso Brasileiro de Oceanografia 09 a 12 de Outubro de 2005-Vitória-ES-Brasil. p. 3.

Walstra, L.C., Van Rijn, L.C., Blogg, H., Van Ormondt, M., 2001. Evaluation of a hydrodynamic area model based on the COAST3D data at Teignmouth 1999, Report TR121-EC MAST Project No. MAS3-CT97-0086. HR Wallinford, UK, pp. D4.1-D4.4.

Wang, H., Yang, Z., Li, Y., Guo, Z., Sun, X., Wang, Y., 2007. Dispersal pattern of suspended sediment in the shear frontal zone off the Huanghe (Yellow River) mouth. Continental Shelf Research 27, 854-871.

Warrick, J.A., DiGiacomo, P.M., Weisberg, S.B., Nezlin, N.P., Mengel, M., Jones, B.H., Ohlmann, J.C., Washburn, L., Terril, E.J., Farnsworth, K.L., 2007. River plume patterns and dynamics within the southern California bight. Continental Shelf Research 27, 2427-2448.

Wright, L.D., Friedrichs, C.T., 2006. Gravity-driven sediment transport on continental shelves: A status report. Continental Shelf Research 26, 2092-2107.

Wright, I.D., Nittrouer, C.A., 1995. Dispersal of river sediments in coastal seas: six contrasting cases. Estuaries 18, 494-508.

Xia, M., Xie, L., Pietrafesa, L.J., 2007. Modeling of the Cape Fear River estuary plume. Estuaries and Coasts 30 (4), 698-709.

Zavialov, P.O., Kostinoy, A.G., Möller, O.O., 2003. Mapping river discharge effects on Southern Brazilian shelf. Geophysical Research Letters 30 (21), 2126.

Zhang, Q.H., Janovitz, G.S., Pietrafesa, L.J., 1987. The interaction of estuarine and shelf waters: a model and applications. Journal of Physical Oceanography 17, 455-469.

Zimmerman, J.T.F., 1981. Dynamics, diffusion and geomorphological significance of tidal residual eddies. Nature 290, 549-555. 